\title{
Biogeochemical and plant trait mechanisms drive enhanced methane emissions in response to whole-ecosystem warming
}

\author{
Genevieve L. Noyce and J. Patrick Megonigal \\ Smithsonian Environmental Research Center, Edgewater, MD, USA \\ Correspondence: Genevieve L. Noyce (noyceg@ si.edu)
}

Received: 9 October 2020 - Discussion started: 25 November 2020

Revised: 22 February 2021 - Accepted: 9 March 2021 - Published: 19 April 2021

\begin{abstract}
Climate warming perturbs ecosystem carbon (C) cycling, causing both positive and negative feedbacks on greenhouse gas emissions. In 2016, we began a tidal marsh field experiment in two vegetation communities to investigate the mechanisms by which whole-ecosystem warming alters $\mathrm{C}$ gain, via plant-driven sequestration in soils, and $\mathrm{C}$ loss, primarily via methane $\left(\mathrm{CH}_{4}\right)$ emissions. Here, we report the results from the first 4 years. As expected, warming of $5.1{ }^{\circ} \mathrm{C}$ more than doubled $\mathrm{CH}_{4}$ emissions in both plant communities. We propose this was caused by a combination of four mechanisms: (i) a decrease in the proportion of $\mathrm{CH}_{4}$ consumed by $\mathrm{CH}_{4}$ oxidation, (ii) more $\mathrm{C}$ substrates available for methanogenesis, (iii) reduced competition between methanogens and sulfate-reducing bacteria, and (iv) indirect effects of plant traits. Plots dominated by Spartina patens consistently emitted more $\mathrm{CH}_{4}$ than plots dominated by Schoenoplectus americanus, indicating key differences in the roles these common wetland plants play in affecting anaerobic soil biogeochemistry and suggesting that plant composition can modulate coastal wetland responses to climate change.
\end{abstract}

\section{Introduction}

Methane $\left(\mathrm{CH}_{4}\right)$ is a potent greenhouse gas that contributes to $15 \%-19 \%$ of total greenhouse gas radiative forcing (IPCC, 2013) and has a sustained-flux global warming potential that is 45 times that of $\mathrm{CO}_{2}$ on a 100 -year timescale (Neubauer and Megonigal, 2015). Wetlands are the largest natural source of $\mathrm{CH}_{4}$ to the atmosphere and were recently identified as the largest source of uncertainty in the global $\mathrm{CH}_{4}$ budget (Saunois et al., 2016). Recent estimates calculate that $\mathrm{CH}_{4}$ emissions from vegetated coastal wetlands offset 3.6 of the 12.2 million metric tons (MMT) of $\mathrm{CO}_{2}$ equivalents accumulated by these ecosystems each year (EPA, 2017). Despite this, there is still a substantial knowledge gap regarding how global change factors, such as climate warming, will alter coastal wetland $\mathrm{CH}_{4}$ emissions (Mcleod et al., 2011) even though these feedbacks have the potential to shift coastal wetlands from being a net sink of $\mathrm{C}$ to a net source (Al-Haj and Fulweiler, 2020; Bridgham et al., 2006).

The net flux of $\mathrm{CH}_{4}$ to the atmosphere from any ecosystem represents the balance between the amount of $\mathrm{CH}_{4}$ produced (methanogenesis), the amount of $\mathrm{CH}_{4}$ oxidized (methanotrophy), and the rate of $\mathrm{CH}_{4}$ transport from the soil. In coastal wetlands, methanogenesis occurs through three pathways: (i) hydrogenotrophic methanogenesis (i.e., $\mathrm{CO}_{2}$ reduction) in which $\mathrm{H}_{2}$ is the electron donor and $\mathrm{CO}_{2}$ is the electron acceptor; (ii) acetoclastic methanogenesis, in which acetate $\left(\mathrm{CH}_{4} \mathrm{COOH}\right)$ is split into $\mathrm{CH}_{4}$ and $\mathrm{CO}_{2}$; and (iii) methylotrophic methanogenesis in which methylated compounds are converted to $\mathrm{CH}_{4}$ and $\mathrm{CO}_{2}$ (Conrad, 2020; Oremland et al., 1982; Schlesinger and Bernhardt, 2020). Rates of methanogenesis are driven by low-redox conditions and substrate availability, while aerobic $\mathrm{CH}_{4}$ oxidation requires both $\mathrm{O}_{2}$ and $\mathrm{CH}_{4}$ as substrates. Roots and rhizomes in wetland ecosystems influence methane-related substrates through at least two mechanisms: (i) deposition of organic compounds that support multiple pathways of heterotrophic microbial respiration, including methanogenesis, and (ii) release of $\mathrm{O}_{2}$ that simultaneously promotes $\mathrm{CH}_{4}$ oxidation and regeneration of competing electron acceptors such as $\mathrm{Fe}(\mathrm{III})$ and $\mathrm{SO}_{4}$ (Philippot et al., 2009; Stanley and Ward, 2010). Root exudates, which typically include low-molecular-weight compounds, may either be more readily used by microbes than 
existing soil C (Kayranli et al., 2010; Megonigal et al., 1999) or prime microbial use of soil C (Basiliko et al., 2012; Philippot et al., 2009; Robroek et al., 2016; Waldo et al., 2019). Root exudates can also decrease $\mathrm{CH}_{4}$ oxidation by stimulating use of $\mathrm{O}_{2}$ by other aerobic microbes (Lenzewski et al., 2018; Mueller et al., 2016). Consequently, wetland $\mathrm{CH}_{4}$ emissions are strongly linked to a wide variety of plant traits that govern the supply of reductive (organic carbon) and oxidative $\left(\mathrm{O}_{2}\right)$ substrates to soils (Moor et al., 2017; Mueller et al., 2020).

Although it is understood that wetland plants are a primary control on $\mathrm{CH}_{4}$ emissions and that much of their influence is mediated through conditions in the rhizosphere (Waldo et al., 2019), there are surprisingly few data, especially from coastal wetlands, that couple plant responses to the dynamics of electron donors (organic $\mathrm{C}$ ), electron acceptors $\left(\mathrm{O}_{2}, \mathrm{SO}_{4}\right)$, and the rates of competing (sulfate reduction vs. methanogenesis) or opposing $\left(\mathrm{CH}_{4}\right.$ production vs. $\mathrm{CH}_{4}$ oxidation) microbial processes. The general lack of process data on wetland $\mathrm{CH}_{4}$ cycling makes it difficult to forecast ecosystem responses to climate change. For example, the well-documented observation that warming increases wetland methane emissions can be either amplified or dampened depending on changes in plant activity (e.g., primary production) or plant traits (e.g., community composition) (Mueller et al., 2020). Vegetation composition has been shown to be a stronger control on $\mathrm{CH}_{4}$ emissions than $\sim 1^{\circ} \mathrm{C}$ of warming in northern peatlands (Ward et al., 2013), and Chen et al. (2017) proposed that warming effects on plant functional types can drive $\mathrm{C}$ flux responses that cannot otherwise be explained by abiotic conditions. In freshwater marshes, plant species and growth trends have also been linked to seasonal shifts in pools of dissolved $\mathrm{CH}_{4}$ and dissolved inorganic carbon (DIC; Ding et al., 2005; Stanley and Ward, 2010) and methanogenesis dynamics (Sorrell et al., 1997).

Tidal wetlands are particularly good model systems for determining the mechanisms by which warming alters $\mathrm{CH}_{4}$ emissions. Not only will the $\mathrm{CH}_{4}$ cycle respond to the direct effects of warming, but the temperature effects on the outcome of competition for electron acceptors are relatively easily observed because of the abundance of $\mathrm{SO}_{4}$. Thermodynamic theory in which terminal electron acceptors (TEAs) are used in order of decreasing thermodynamic yield is commonly interpreted to mean that a system will support only one form of anaerobic respiration at a time, with acetoclastic and hydrogenotrophic methanogenesis occurring only when pools of more energetically favorable TEAs have been depleted (Conrad, 2020; Schlesinger and Bernhardt, 2020). However, in real systems with spatial and temporal variability in the supply of electron donor substrates and TEAs, all forms of anaerobic metabolism occur simultaneously (Megonigal et al., 2004; Bridgham et al., 2013). Much of this spatial and temporal variation arises from the distribution and activity of roots and rhizomes as mediated by the rhizosphere (Neubauer et al., 2008). Global change factors such as warm- ing will further affect the spatial distribution of key metabolic substrates. In addition, the relatively limited species diversity in saline tidal wetlands allows species-level effects on $\mathrm{CH}_{4}$ cycling to be delineated more easily than in diverse freshwater wetlands.

Methane flux measurements are a metric of broader shifts in redox potential and biogeochemical cycling, as they are sensitive to virtually all processes that regulate availability of electron donors and electron acceptors. Emissions are commonly predicted to increase with future climate warming, including from coastal wetlands (Al-Haj and Fulweiler, 2020), but there is minimal prior understanding of the underlying mechanisms, which was the focus of this study. Our objectives were to explore the mechanisms that drive enhanced $\mathrm{CH}_{4}$ emissions under warming. To accomplish this, we measured monthly $\mathrm{CH}_{4}$ emissions from 2016 through 2019 and coupled these flux measurements with analysis of porewater biogeochemistry and vegetation biomass and composition.

\section{Materials and methods}

\subsection{Site description and experimental design}

The Salt Marsh Accretion Response to Temperature eXperiment (SMARTX) was established in the Smithsonian's Global Change Research Wetland (GCReW) in 2016. GCReW is part of Kirkpatrick Marsh, a microtidal, brackish high marsh on the western shore of the Chesapeake Bay, USA $\left(38^{\circ} 53^{\prime} \mathrm{N}, 76^{\circ} 33^{\prime} \mathrm{W}\right)$. Soils are organic $(>80 \%$ organic matter) to a depth of $5 \mathrm{~m}$, which is typical of high marshes in the Chesapeake Bay and elsewhere. The very low mineral content $(<20 \%)$ affects methane dynamics because negligible competition between methanogens and ironreducing bacteria for electron donors is expected in the absence of a significant pool of poorly crystalline iron oxides (Roden and Wetzel, 1996), as has been documented previously at this site (Weiss et al., 2004). Soil bulk density in the upper $60 \mathrm{~cm}$ averages $0.124 \mathrm{~g} \mathrm{~cm}^{3}$ and ranges from 0.079 to $0.180 \mathrm{~g} \mathrm{~cm}^{3}$. The relatively uniform bulk density of the soil profile reflects the uniform soil organic matter content and the fact that bulk density becomes largely independent of organic matter and mineral content once organic matter content exceeds $50 \%$ (Holmquist et al., 2018). The marsh is typically saturated to within $5-15 \mathrm{~cm}$ of the soil surface, but inundation frequency varies across the site, from $10 \%-20 \%$ of high tides in high-elevation areas to $30 \%-60 \%$ of high tides in low-elevation areas.

SMARTX consists of six replicate transects, three located in each of the two dominant annual plant communities (Fig. S1). In the $\mathrm{C}_{3}$-dominated community (herein the " $\mathrm{C}_{3}$ community") the $\mathrm{C}_{3}$ sedge Schoenoplectus americanus (herein Schoenoplectus) composes more than $90 \%$ of the aboveground biomass (Table 1). In the $\mathrm{C}_{4}$-dominated community (herein the " $\mathrm{C}_{4}$ community"), $75 \%$ of the above- 
Table 1. Relative contribution to total aboveground biomass from $\mathrm{C}_{3}$ sedges (Schoenoplectus americanus) and $\mathrm{C}_{4}$ grasses (Spartina patens and Distichlis spicata) in each plant community. Values are means and $\operatorname{SE}(n=12)$.

\begin{tabular}{lrr|rr}
\hline & \multicolumn{2}{c|}{$\mathrm{C}_{3}$ community } & \multicolumn{2}{c}{$\mathrm{C}_{4}$ community } \\
\cline { 2 - 5 } Year & $\% \mathrm{C}_{3}$ & $\% \mathrm{C}_{4}$ & $\% \mathrm{C}_{3}$ & $\% \mathrm{C}_{4}$ \\
\hline 2016 & $93(3)$ & $8(3)$ & $8(2)$ & $76(6)$ \\
2017 & $91(3)$ & $9(3)$ & $10(3)$ & $64(4)$ \\
2018 & $95(1)$ & $5(1)$ & $15(4)$ & $65(7)$ \\
2019 & $93(2)$ & $4(1)$ & $23(5)$ & $56(6)$ \\
\hline
\end{tabular}

ground biomass was initially composed of two $\mathrm{C}_{4}$ grasses (Spartina patens and Distichlis spicata, herein Spartina and Distichlis, respectively). However, by 2019, Spartina and Distichlis declined to $56 \%$ of the aboveground biomass (Table 1).

Each transect is an active warming gradient consisting of unheated ambient plots and plots that are heated to 1.7, 3.4, and $5.1^{\circ} \mathrm{C}$ above ambient. All plots are $2 \mathrm{~m} \times 2 \mathrm{~m}$ with a $20 \mathrm{~cm}$-wide buffer around the perimeter. Aboveground plantsurface temperature is elevated via infrared heaters, and soil temperature is elevated via vertical resistance cables (Rich et al., 2015). Soils are heated to a depth of $1.5 \mathrm{~m}$, which is the depth most vulnerable to climate or human disturbance (Pendleton et al., 2012). Aboveground and belowground temperature variation are assessed via thermocouples embedded in acrylic plates at plant canopy level and inserted into the soil, respectively, and the temperature gradient is maintained by integrated microprocessor-based feedback control (Rich et al., 2015). Noyce et al. (2019) provide additional details of the heating system. Warming began on 1 June 2016 and has continued year-round.

\subsection{Methane flux measurements}

Methane emissions were measured monthly year-round from May 2016 to December 2019 using a static chamber system. One permanent $160 \mathrm{~cm}^{2}$ aluminum base was inserted $10 \mathrm{~cm}$ into the soil in each plot in April 2016. On each measurement date, clear chambers $(40 \mathrm{~cm} \times 40 \mathrm{~cm} \times 40 \mathrm{~cm})$ were gently placed on top of each base and secured with compression clips. Chambers consisted of an aluminum frame with transparent sides made of polychlorotrifluoroethylene film (Honeywell International) and closed-cell foam on the base. Depending on the height of the vegetation at the time of measurement, chambers were stacked up to four high (total height of 40-160 cm) (Fig. S2). The advantage of this stacking method is that it uses the minimal chamber volume necessary, while also allowing for plant growth. After placement, the chambers were left open for at least $10 \mathrm{~min}$, to minimize disturbance effects and allow air inside the chamber to return to ambient conditions. During data collection, chambers were covered with a transparent polycarbonate top equipped with sampling tubes, a fan to circulate air inside the chambers, a PAR sensor, and thermocouples. The sealed chamber was covered with a foil shroud to block out all light and to minimize changes in temperature and relative humidity during the measurement period. An Ultraportable Greenhouse Gas Analyzer (Los Gatos Research, CA) was used to measure headspace $\mathrm{CH}_{4}$ concentrations for $5 \mathrm{~min}$. Plots were accessed from permanent boardwalks elevated $15 \mathrm{~cm}$ above the soil surface to avoid compressing the surrounding peat and altering diffusive $\mathrm{CH}_{4}$ emissions. Fluxes were calculated as the slope of the linear regression of $\mathrm{CH}_{4}$ concentration over time. The 40 fluxes where $p>0.05$ were assigned a value of one-half the limit of detection of the system (Wassmann et al., 2018; Table S1). This was $1 \%$ of fluxes during the growing season and $4.5 \%$ of fluxes over the remaining months. For 2017-2019, monthly measurements were scaled to annual estimates by regressing $\mathrm{CH}_{4}$ emissions against daily mean soil temperature and day of year (as a proxy for phenological status). Annual estimates were not calculated for 2016 because flux measurements did not start until May.

\subsection{Porewater sampling and analysis}

Porewater samples were collected in May, July, and September of each year using stainless-steel "sippers" permanently installed in each plot. Each sipper consisted of a length of stainless-steel tubing, crimped and sealed at the end, with several slits (approximate width $0.8 \mathrm{~mm}$ ) cut in the bottom $2 \mathrm{~cm}$. The aboveground portion of each sipper was connected to Tygon Masterflex ${ }^{\circledR}$ tubing capped with a two-way stopcock. In May 2016, duplicate clusters of sippers were installed in each of the 30 plots at $20,40,80$, and $120 \mathrm{~cm}$ below the soil surface. An additional set of $10 \mathrm{~cm}$ deep sippers was installed in 2017. In this study we defined samples from $10-20 \mathrm{~cm}$ as "rooting zone" samples and samples from 40$120 \mathrm{~cm}$ as "deep peat" samples. On sampling dates, porewater sitting in the sippers was drawn up and discarded, after which $60 \mathrm{~mL}$ of porewater from each depth $(30 \mathrm{~mL}$ from each sipper) was withdrawn and stored in syringes equipped with three-way stopcocks. A $10 \mathrm{~mL}$ aliquot of each sample was filtered through a pre-leached $0.45 \mu \mathrm{m}$ syringe-mounted filter, preserved with $5 \%$ zinc acetate and sodium hydroxide, and frozen for future $\mathrm{SO}_{4}$ and $\mathrm{Cl}$ analysis. Dissolved $\mathrm{CH}_{4}$ was extracted from $15 \mathrm{~mL}$ of porewater in the syringe by drawing $15 \mathrm{~mL}$ of ambient air and shaking vigorously for $2 \mathrm{~min}$ to allow the dissolved $\mathrm{CH}_{4}$ to equilibrate with the headspace. Headspace subsamples were then immediately analyzed on a Shimadzu GC-14A gas chromatograph equipped with a flame ionization detector. A total of $3 \mathrm{~mL}$ of porewater was used to measure $\mathrm{pH}$ using a Fisher Scientific accumet electrode (13-620-290). The remaining porewater was used to measure $\mathrm{H}_{2} \mathrm{~S}$ and $\mathrm{NH}_{4}$; those data are not reported here.

$\mathrm{SO}_{4}$ and $\mathrm{Cl}$ were measured on a Dionex ICS-2000 ion chromatography system (2016-2018) or a Dionex Inte- 
grion (2019). On the Dionex ICS-2000 samples were separated using an A11 column with $30 \mathrm{mM}$ of $\mathrm{KOH}$ as eluent; on the Dionex Integrion samples were separated using an A11 $4 \mu \mathrm{m}$ fast column with $35 \mathrm{mM} \mathrm{KOH}$. Sulfate depletion (Sulfate ${ }_{\text {Dep }}$ ) was calculated based on measured porewater concentrations of $\mathrm{SO}_{4}\left(\mathrm{SO}_{4 \mathrm{pw}}\right)$ and $\mathrm{Cl}\left(\mathrm{Cl}_{\mathrm{pw}}\right)$ and the constant molar ratio of $\mathrm{Cl}$ to $\mathrm{SO}_{4}$ in surface seawater $\left(R_{\mathrm{Sw}}=19.33\right.$; Bianchi, 2006) using the following equation: Sulfate $_{\text {Dep }}=\mathrm{Cl}_{\mathrm{pw}} / R_{\mathrm{Sw}}-\mathrm{SO}_{4 \mathrm{pw}}$. If driven only by seawater inputs, the ratio of $\mathrm{Cl}$ to $\mathrm{SO}_{4}$ would remain constant, but under anaerobic conditions $\mathrm{SO}_{4}$ can be reduced by sulfatereducing bacteria, altering this ratio. As a result, $\mathrm{SO}_{4}$ depletion can be used as a proxy for $\mathrm{SO}_{4}$ reduction rates.

\subsection{Plant biomass measurements}

Measurements of Schoenoplectus, Spartina, and Distichlis biomass were conducted during peak biomass of each year (29 July-2 August) as described by Noyce et al. (2019). Schoenoplectus biomass was estimated using non-destructive allometric techniques (Lu et al., 2016) in $900 \mathrm{~cm}^{2}$ quadrats, and Spartina and Distichlis biomass were estimated through destructive harvest of $25 \mathrm{~cm}^{2}$ subplots.

\subsection{Data analysis}

Statistics were conducted in R (version 3.6.3). Methane flux (Fig. S3) and porewater data were log transformed to become normally distributed prior to statistical analyses. The "growing season" was defined as May through September based on Schoenoplectus growth trends (Fig. S4). Pearson's correlations were used to test the relationships between $\mathrm{CH}_{4}$ flux and soil temperature as well as $\mathrm{CH}_{4}$ flux and plant biomass. Responses of $\mathrm{CH}_{4}$ emissions to vegetation type and warming treatment were analyzed using linear mixed models with vegetation community and warming treatment as categorical variables and plot and year as random effects. $P$ values were calculated using Satterthwaite's method, and Tukey's post hoc tests were used to compare individual means. Porewater data were averaged per year and then analyzed using one-way ANOVAs to determine the effects of warming treatment or plant community, applying Tukey's HSD test for post hoc analyses.

\section{Results}

\subsection{Environmental conditions, site characteristics, and experiment performance}

The growing season of 2016 was the hottest of the 4 years, with growing season temperatures averaging $>1{ }^{\circ} \mathrm{C}$ above the other 3 years (Table 2). While 2017 through 2019 had similar summer temperatures, they had very different precipitation regimes: 2018 was much wetter on average and 2019 was slightly drier (Table 2). During all years, temperatures in
Table 2. Growing season (May-September) temperature and precipitation. Temperature data are means (SE) of daily averages from ambient plots, and precipitation is the total from May through September.

\begin{tabular}{rrrr}
\hline Year & $\begin{array}{r}\text { Mean } \\
\text { aboveground } \\
\text { temperature } \\
\left({ }^{\circ} \mathrm{C}\right)\end{array}$ & $\begin{array}{r}\text { Mean } \\
\text { soil }\end{array}$ & $\begin{array}{r}\text { Total } \\
\text { temperature } \\
\left({ }^{\circ} \mathrm{C}\right)\end{array}$ \\
\hline 2016 & $24.7(0.3)$ & $22.4(0.2)$ & 51.0 \\
2017 & $22.0(0.3)$ & $20.7(0.2)$ & 51.1 \\
2018 & $23.7(0.3)$ & $20.8(0.2)$ & 86.4 \\
2019 & $23.6(0.3)$ & $20.9(0.2)$ & 43.7 \\
\hline
\end{tabular}

the experimental plots were successfully shifted by the target differentials of $+1.7,+3.4$, and $+5.1^{\circ} \mathrm{C}$ above the ambient plots (Fig. 1 (top); Noyce et al., 2019). Porewater pH ranged from 6.4 to 6.8 across the measurement period, with no effect of temperature treatment ( $p>0.1$; data not shown). There was no difference in soil bulk density between the ambient and $+5.1{ }^{\circ} \mathrm{C}$ plots after 4.5 years of warming ( $p=0.54$; data not shown).

\subsection{Methane fluxes}

Methane emissions increased with soil temperature $\left(R^{2}=0.41, p<0.001\right)$ (Fig. 1). Emissions from all treatments had strong seasonal trends; fluxes were highest in the $\mathrm{C}_{3}$ community in June through August and peak fluxes in the $\mathrm{C}_{4}$ community were shifted about a month later to July through September (Fig. S3). Whole-ecosystem warming increased $\mathrm{CH}_{4}$ emissions throughout the growing season $\left(F_{3,400}=5.1, p=0.002\right.$; Fig. 2$)$. Across all 4 years, $5.1{ }^{\circ} \mathrm{C}$ of warming more than doubled growing season emissions, from 624 to $1413 \mu \mathrm{mol} \mathrm{CH}_{4} \mathrm{~m}^{-2} \mathrm{~d}$ ( $p_{\text {adj }}=0.02$; Fig. 2).

Mean $\mathrm{CH}_{4}$ emissions were higher from the $\mathrm{C}_{4}$ community than from the $\mathrm{C}_{3}$ community both during the growing season $\left(F_{1,22}=13.6, p=0.001\right.$; Fig. $\left.3 \mathrm{a}\right)$ and on an annual basis $\left(F_{1,22}=8.5, p=0.008\right.$; Fig. $\left.3 b\right)$. Mean annual $\mathrm{CH}_{4}$ emissions ranged from $58 \mathrm{mmol} \mathrm{CH}_{4}$ (ambient) to $343 \mathrm{mmol} \mathrm{CH}_{4} \mathrm{~m}^{-2} \mathrm{yr}^{-1}\left(+5.1^{\circ} \mathrm{C}\right)$ in the $\mathrm{C}_{3}$ community and from $55 \mathrm{mmol} \mathrm{CH}_{4}$ (ambient) to $879 \mathrm{mmol} \mathrm{CH}_{4} \mathrm{~m}^{-2} \mathrm{yr}^{-1}$ $\left(+5.1^{\circ} \mathrm{C}\right)$ in the $\mathrm{C}_{4}$ community (Table S2). Under ambient conditions, growing season $\mathrm{CH}_{4}$ fluxes were almost twice as large from $\mathrm{C}_{4}$ plots, whereas under low warming (1.7 to $3.4^{\circ} \mathrm{C}$ ) this difference increased to more than 3 times as large (Fig. 3a). From 2017-2019, $\mathrm{CH}_{4}$ emissions were positively related to Spartina and Distichlis aboveground biomass across all warming treatments and negatively related to Schoenoplectus biomass (Fig. 4a, b). In 2016, however, the direction of those relationships in both plant communities were the exact opposite, with Spartina and Distichlis biomass negatively related, and Schoenoplectus biomass positively related, to $\mathrm{CH}_{4}$ emissions (Fig. 4a, b). 


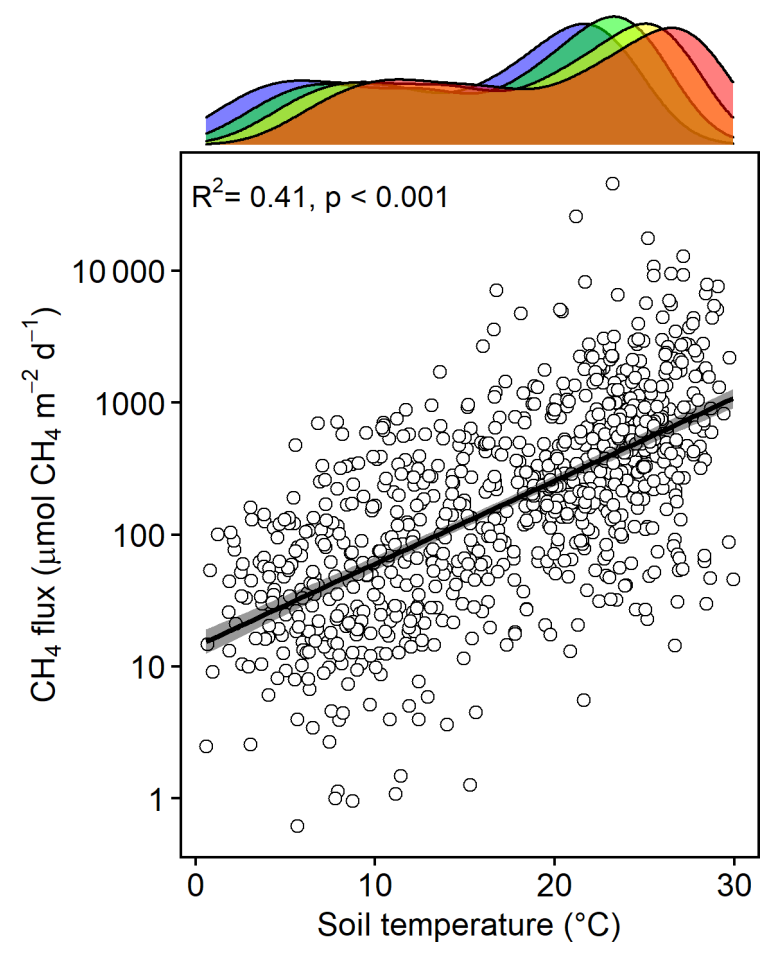

Figure 1. Bottom: $\mathrm{CH}_{4}$ emissions from each plot versus the soil temperature at the time of measurement. Top: density plot depicting the range of soil temperatures in each treatment, delineated by color: ambient (blue), +1.7 (green), +3.4 (yellow), and $+5.1{ }^{\circ} \mathrm{C}$ (red).

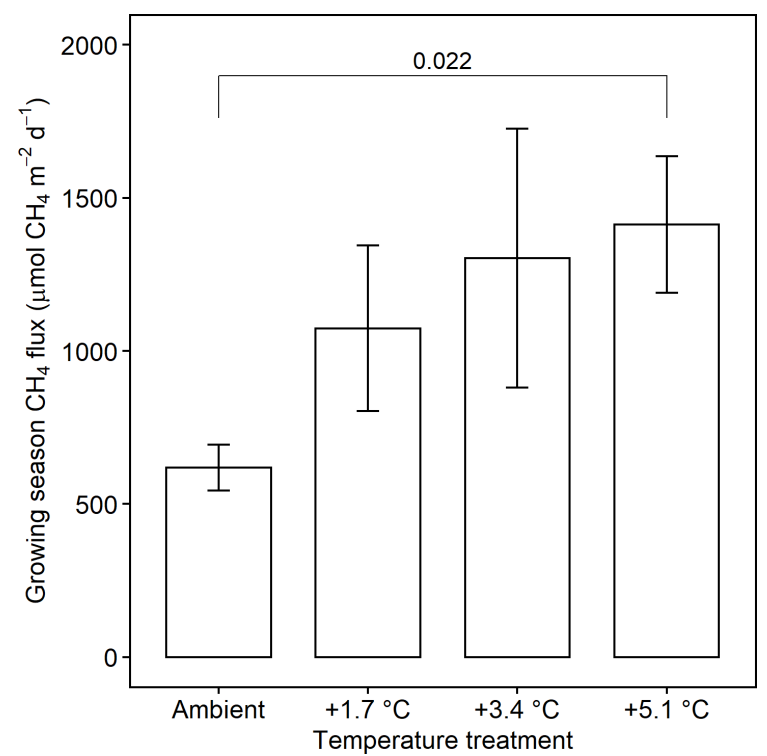

Figure 2. Comparison of $\mathrm{CH}_{4}$ emissions from each warming treatment during the growing season (May-September). Means include both the $\mathrm{C}_{3}$ and $\mathrm{C}_{4}$ community and all years of measurement. Error bars indicate SE. Horizonal bars indicate means that are significantly different and the corresponding $p_{\text {adj }}$.

\subsection{Porewater chemistry}

Under ambient conditions, porewater collected from the $\mathrm{C}_{4}$ community had more dissolved $\mathrm{CH}_{4}\left(F_{1,22}=18.4\right.$, $p<0.001$; Fig. 5a, b), less $\mathrm{SO}_{4}\left(F_{1,22}=29.1, p<0.001\right.$; Fig. 6a), and similar salinity $(p=0.068)$ compared to the $\mathrm{C}_{3}$ community. In the $\mathrm{C}_{3}$ community, warming increased dissolved $\mathrm{CH}_{4}$ in both the rooting zone porewater (10$20 \mathrm{~cm})\left(F_{3,44}=2.85, p=0.048\right.$; Fig. 5a) and in the deep peat $(40-120 \mathrm{~cm})\left(F_{3,44}=6.23, p=0.001\right.$; Fig. $\left.5 \mathrm{~b}\right)$. Dissolved $\mathrm{CH}_{4}$ concentrations were relatively similar in the ambient, +1.7 , and $+3.4{ }^{\circ} \mathrm{C}$ treatments but more than doubled with $+5.1^{\circ} \mathrm{C}$ of warming in both the rooting zone (59 to $\left.125 \mu \mathrm{mol} \mathrm{CH}_{4} \mathrm{~L}^{-1}, p_{\mathrm{adj}}<0.001\right)$ and the deeper porewater (43 to $1254 \mu \mathrm{mol} \mathrm{CH}_{4} \mathrm{~L}^{-1}, p_{\text {adj }}<0.001$ ). In the $\mathrm{C}_{4}$ community there was minimal effect of warming treatment on porewater in the rooting zone $\left(F_{3,44}=0.442, p=0.72\right.$; Fig. $\left.5 a\right)$, but all levels of warming decreased dissolved $\mathrm{CH}_{4}$ below $40 \mathrm{~cm}\left(F_{3,44}=129.3, p<0.001\right)$, with concentrations in the +3.4 and +5.1 plots less than a third of the concentrations in the ambient plots ( 155 vs. 56 and $40 \mu \mathrm{mol} \mathrm{CH}_{4} \mathrm{~L}^{-1}$, $p_{\text {adj }}<0.001$; Fig. 5b).

In the $\mathrm{C}_{3}$ community, $\mathrm{SO}_{4}$ concentrations decreased with warming $\left(F_{3,44}=3.76, p=0.017\right)$, but warming effects on $\mathrm{SO}_{4}$ cycling in the $\mathrm{C}_{4}$ community were more mixed with $+3.4^{\circ} \mathrm{C}$ increasing $\mathrm{SO}_{4}\left(p_{\text {adj }}=0.048\right)$ but no other treatments having large effects (Fig. 6a). In all plots, the measured concentrations of rooting-zone $\mathrm{SO}_{4}$ were lower than expected based on salinity (Fig. 6b), indicating that $\mathrm{SO}_{4}$ reduction occurred. In both plant communities, the $+5.1^{\circ} \mathrm{C}$ treatments increased this $\mathrm{SO}_{4}$-depletion effect compared to ambient, though the effect was stronger in the $\mathrm{C}_{3}$ community $(p<0.001)$ than the $\mathrm{C}_{4}$ community $(p=0.04)$ (Fig. 6b). Dissolved $\mathrm{CH}_{4}$ was highest in both plant communities when $\mathrm{SO}_{4}$ concentrations were $<5 \mathrm{mmol} \mathrm{SO}_{4} \mathrm{~L}^{-1}$ (Fig. S5).

\section{Discussion}

Soil temperature (both seasonal and experimental) and plant traits were both strong drivers of $\mathrm{CH}_{4}$ emissions from this site. This follows prior field, mesocosm, and incubation studies across a variety of wetlands, in which temperature has been shown to be a strong predictor of $\mathrm{CH}_{4}$ emissions (e.g., Al-Haj and Fulweiler, 2020; van Bodegom and Stams, 1999; Christensen et al., 2003; Dise et al., 1993; Fey and Conrad, 2000; Liu et al., 2019; Ward et al., 2013; Yang et al., 2019; Yvon-Durocher et al., 2014) and in which plant functional type has an interacting effect (e.g., Chen et al., 2017; Duval and Radu, 2018; Liu et al., 2019; Mueller et al., 2020; Ward et al., 2013). Methane emissions are a function of the balance between methanogenesis, $\mathrm{CH}_{4}$ oxidation, and $\mathrm{CH}_{4}$ transport, so explaining these results requires some combination of stimulation of methanogenesis, reduction of $\mathrm{CH}_{4}$ oxidation, or increase in $\mathrm{CH}_{4}$ transport. 


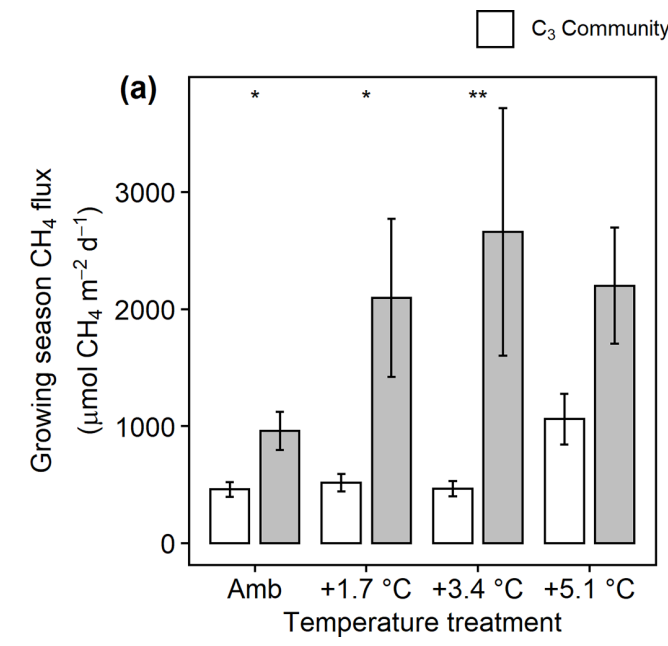

$\square \mathrm{C}_{4}$ Community

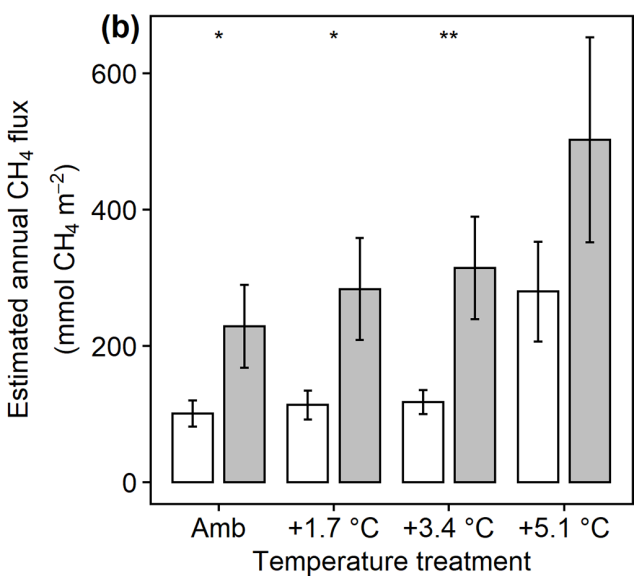

Figure 3. Comparison of $\mathrm{CH}_{4}$ emissions from the $\mathrm{C}_{3}$ community dominated by Schoenoplectus (open bars) and the $\mathrm{C}_{4}$ community dominated by Spartina and Distichlis (grey bars). (a) During the growing season (May-September) and (b) scaled to a year. Means are averaged across all sampling dates for 2017-2019. Error bars indicate SE. Asterisks indicate significant differences between $\mathrm{C}_{3}$ and $\mathrm{C}_{4}$ means at a given temperature $\left({ }^{*} p_{\text {adj }}<0.05,{ }^{* *} p_{\text {adj }}<0.01\right)$.
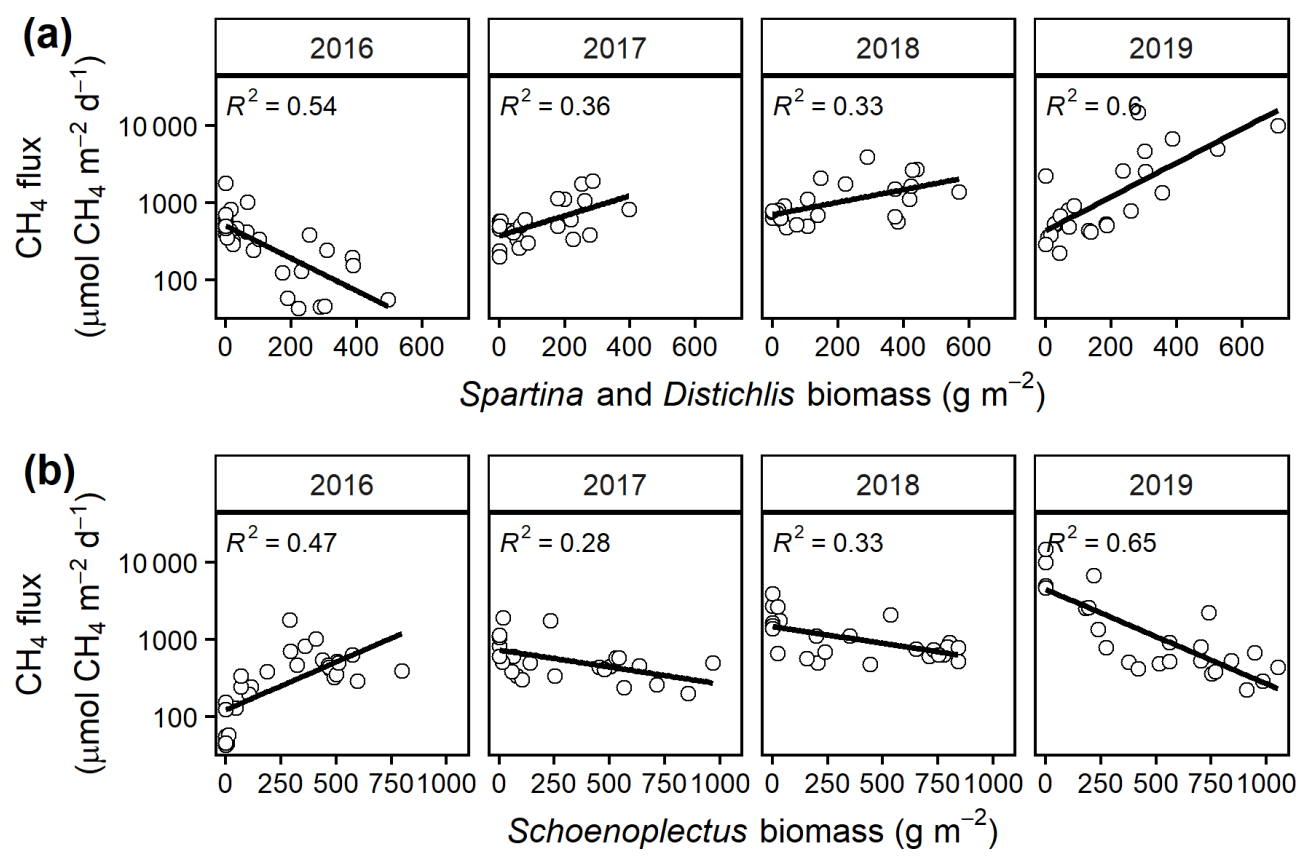

Figure 4. Mean growing season (May-September) $\mathrm{CH}_{4}$ emissions from each plot versus the biomass of (a) $\mathrm{C}_{3}$ (Schoenoplectus) and (b) $\mathrm{C}_{4}$ (Spartina and Distichlis) plants. All regressions are significant at $p=0.05$.

Prior data from brackish wetlands are limited, but incubation studies of freshwater wetland soils typically show large increases in $\mathrm{CH}_{4}$ fluxes with warming (van Bodegom and Stams, 1999; Duval and Radu, 2018; Hopple et al., 2020; Inglett et al., 2012; Sihi et al., 2017; Wilson et al., 2016), indicating that warming alters belowground processes. Though there is some evidence that rhizosphere temperature alters $\mathrm{CH}_{4}$ transport through rice aerenchyma (Hosono and Nouchi, 1997), any transport-driven effects in this ecosys- tem would be transient unless there were a simultaneous increase in net $\mathrm{CH}_{4}$ production (i.e., an increase in methanogenesis that was not completely offset by methanotrophy). Instead, we observed a sustained increase in $\mathrm{CH}_{4}$ emissions, suggesting large shifts in anaerobic metabolism, especially with $+5.1^{\circ} \mathrm{C}$ of warming. We propose four potential and non-exclusive mechanisms to explain the temperature-driven increase in $\mathrm{CH}_{4}$ emissions: (1) shifted ratios of $\mathrm{CH}_{4}$ production to oxidation, (2) increased substrate availability, (3) re- 


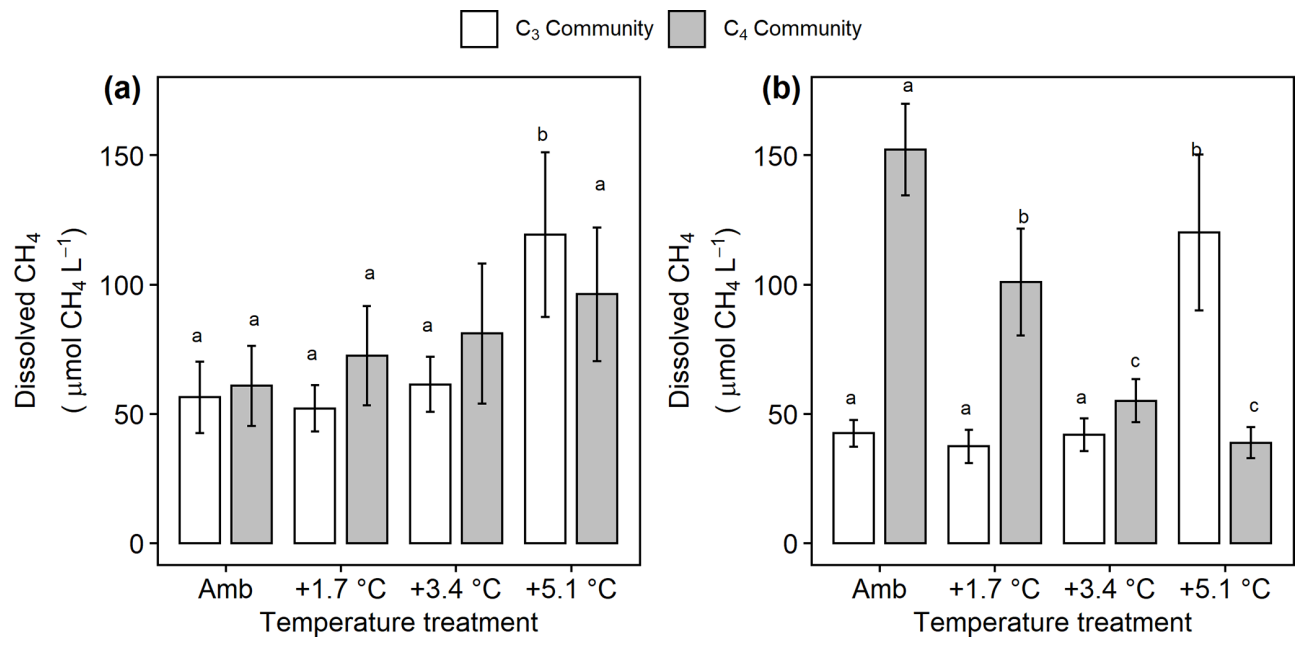

Figure 5. Comparison of dissolved $\mathrm{CH}_{4}$ from the $\mathrm{C}_{3}$ community dominated by Schoenoplectus (open bars) and the $\mathrm{C}_{4}$ community dominated by Spartina and Distichlis (grey bars). (a) In the dominant rooting zone $(10-20 \mathrm{~cm})$ and (b) below the rooting zone $(40-120 \mathrm{~cm})$. Means are averaged across all sampling dates for 2016-2019. Error bars indicate SE. Letters indicate temperature treatments that are significantly different from each other $\left(p_{\text {adj }}<0.05\right)$ within the same plant community.
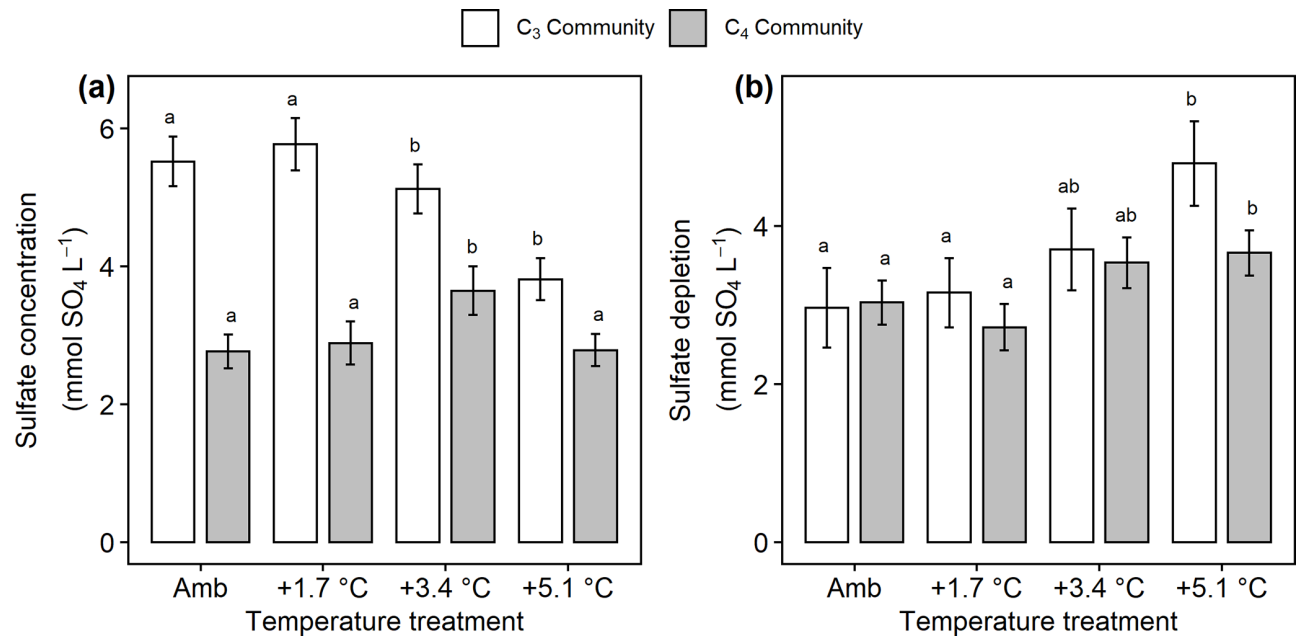

Figure 6. Comparison of sulfate concentrations and estimated sulfate depletion from the $\mathrm{C}_{3}$ community dominated by Schoenoplectus (open bars) and the $\mathrm{C}_{4}$ community dominated by Spartina and Distichlis (grey bars). (a) Sulfate availability throughout the entire soil profile and (b) sulfate depletion in the rooting zone. Means are averaged across all sampling dates for 2016-2019. Error bars indicate SE. Letters indicate temperature treatments that are significantly different from each other $\left(p_{\mathrm{adj}}<0.05\right)$ within the same plant community.

duced competition with sulfate reducers for $\mathrm{H}_{2}$ and organic $\mathrm{C}$, and (4) indirect plant trait effects (Fig. 7).

\subsection{Whole-ecosystem warming promotes methanogenesis over $\mathrm{CH}_{4}$ oxidation}

Holding the supply of substrates and transport properties of the system constant, warming is expected to increase rates of $\mathrm{CH}_{4}$ production relative to $\mathrm{CH}_{4}$ oxidation due solely to differences in the temperature dependence of each process (Megonigal et al., 2016). In wetland soils, the average $Q_{10}$ of methanogenesis is 4.1 compared to 1.9 for aerobic $\mathrm{CH}_{4}$ oxidation (Segers, 1998), which means that a system starting with a given initial ratio between the two processes will become increasingly dominated by methanogenesis as soils warm. A corollary to this expected pattern is that the ratio of the two processes should be constant if the $Q_{10}$ responses are similar, an outcome that was supported with in situ measurements of the two processes in a tidal freshwater forested wetland (Megonigal and Schlesinger, 2002). We did not quantify the temperature dependence of $\mathrm{CH}_{4}$ production and oxidation in the present study, but based on the literature (Segers, 1998) it is likely that methanogenic activity increased more than aerobic methanotrophic activity in direct 

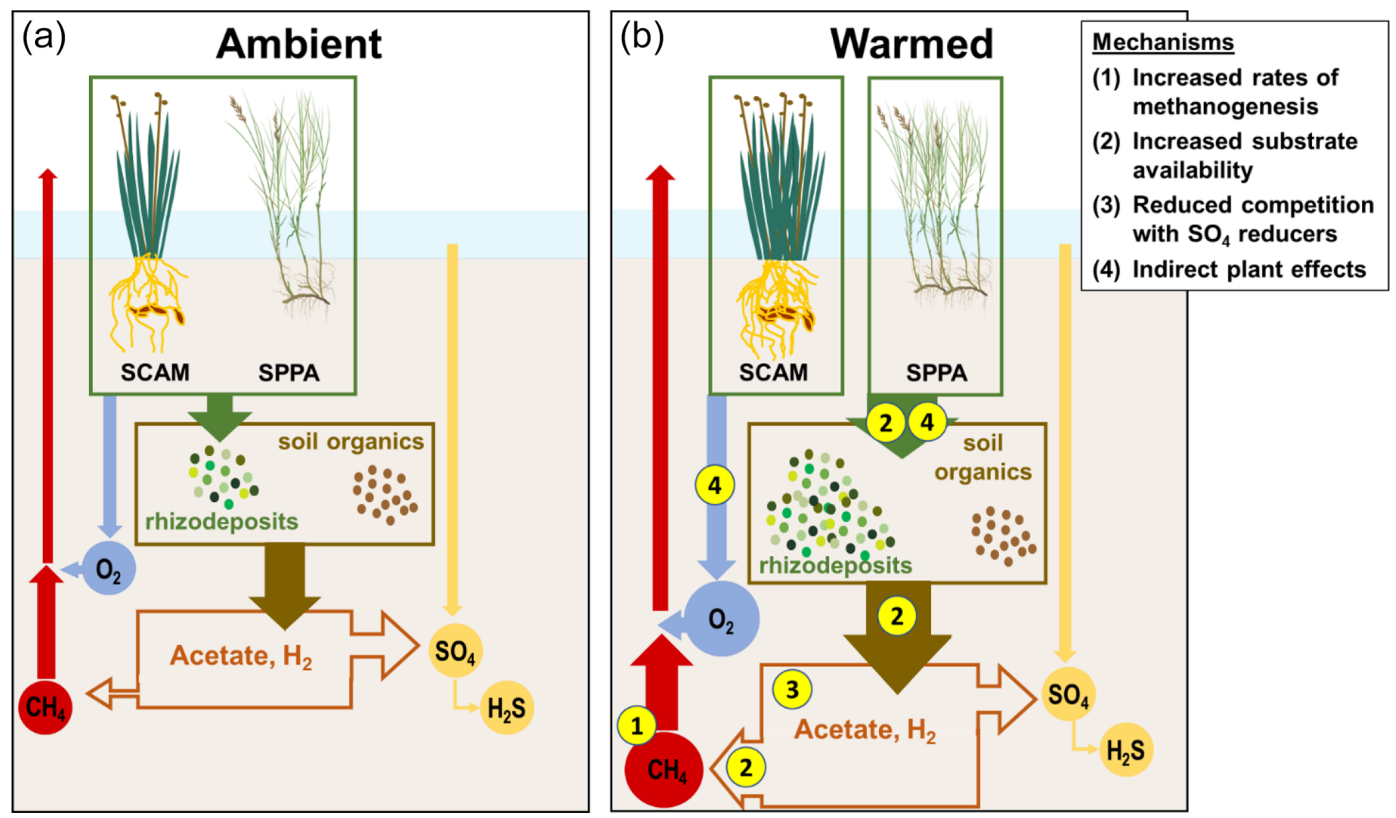

Figure 7. Schematic of mechanisms driving enhanced $\mathrm{CH}_{4}$ emissions in response to warming. SCAM: Schoenoplectus americanus. SPPA: Spartina patens. (a) Processes under ambient conditions. Plants add organic compounds to the soil, which are transformed into other lowmolecular-weight organic compounds. This pool, and processed soil organic matter, support terminal respiration processes dominated by $\mathrm{SO}_{4}$ reduction over $\mathrm{CH}_{4}$ production in organic-rich brackish marsh soils. Plants also transport $\mathrm{O}_{2}$, which supports oxidation of a fraction of the $\mathrm{CH}_{4}$ before it can be transported out of the soil. (b) Processes under warmed conditions. (1) Rates of $\mathrm{CH}_{4}$ production increase more than rates of $\mathrm{CH}_{4}$ oxidation. (2) Substrate availability increases as plants add more rhizodeposits and organic matter is more rapidly fermented to low-molecular-weight organic compounds and $\mathrm{H}_{2}$. (3) The pool of electron donors available to methanogens increases as $\mathrm{SO}_{4}$ reducers become $\mathrm{SO}_{4}$ limited. (4) The dominant plant species have different effects on these processes, with $S$. americanus driving a net increase in $\mathrm{O}_{2}$ transport and $S$. patens driving a net increase in rhizodeposits.

response to warming (Fig. 7, mechanism 1). Evidence for this is that rhizosphere pools of porewater $\mathrm{CH}_{4}$ were highest in the warmest treatment (Fig. 5a); because this occurred despite either no change or an increase in aboveground biomass (Noyce et al., 2019), which would by itself have lowered porewater $\mathrm{CH}_{4}$ due to venting (plant transport), it indicates that $\mathrm{CH}_{4}$ production increased relative to the sum of aerobic and anaerobic methane oxidation.

\subsection{Whole-ecosystem warming increases substrate availability for methanogens}

Methanogenesis can be the terminal step of anaerobic decomposition, but a consortium of microbes is required to break down soil organic matter to electron donor substrates that methanogens can metabolize. The final step in any decomposition pathway involves the flow of electrons from organic matter (electron donors) to a TEA. Under anaerobic conditions, this is accomplished by microbes that tend to specialize in one TEA and compete for organic $\mathrm{C}$ as an electron donor (Megonigal et al., 2004). Consequently, the supply of both electron donors and TEAs regulates the multi-step process of anaerobic decomposition and thus ultimately controls $\mathrm{CH}_{4}$ emissions. For all pathways, methanogenic activity is typically limited by the supply of electron donors, including low-molecular-weight organic compounds (e.g., acetate; Neubauer and Craft, 2009) and $\mathrm{H}_{2}$, a product of organic matter fermentation. We propose that whole-ecosystem warming increases the availability of previously limited $\mathrm{C}$ substrates in two aspects (Fig. 7, mechanism 2).

First, warming may directly influence $\mathrm{C}$ availability through biochemical kinetics. Even if organic inputs remained constant, warming likely accelerates fermentation of soil organic matter, increasing substrate availability for methanogens. Second, the warmed plots had longer growing seasons than the unheated controls (Noyce et al., 2019). This presumably increased inputs of root exudates and fresh detritus, accelerating all forms of heterotrophic microbial respiration by providing organic material that is decomposed into low-molecular-weight organic $\mathrm{C}$ compounds and $\mathrm{H}_{2}$ (Philippot et al., 2009), stimulating growing season $\mathrm{CH}_{4}$ emissions from warmed plots. In 2017, we observed that gross primary production was positively correlated with $\mathrm{CH}_{4}$ emissions and that this effect increased with warming (Fig. S6). Prior studies have also linked $\mathrm{CH}_{4}$ production or emissions to rates of photosynthesis (Vann and Megonigal, 2003), periods of active growth (Chen et al., 2017; Ward et al., 2013), and plant 
senescence, which coincides with a pulse input of labile $\mathrm{C}$ from plants to soils (Bardgett et al., 2005).

Temperature-accelerated biochemical kinetics and increased electron donor supply are mechanisms that can increase methanogenesis without necessarily shifting methanogenic pathways. However, shifts in the balance between hydrogenotrophic, acetoclastic, and methylotrophic methanogenesis pathways can be expected with warming. For example, in Arctic permafrost, methylotrophic methanogenesis was found to be more sensitive to warming than the other pathways (de Jong et al., 2018). Such shifts can be quantified with future analyses of $\mathrm{H}_{2}$ and low-molecularweight organic compounds (e.g., Bridgham et al., 2013; Yang et al., 2016), isotopic tracing of specific methanogenic pathways (e.g., Blaser and Conrad, 2016; Conrad, 2005; Neumann et al., 2016; Whiticar, 1999), and molecular community analyses (e.g., Bridgham et al., 2013; He et al., 2015; Wilson et al., 2016).

\subsection{Whole-ecosystem warming reduces competition with sulfate reducers}

While low-molecular-weight organic compounds are electron donors for acetoclastic methanogenic respiration, they are also substrates for other microbial groups such as $\mathrm{SO}_{4}$ reducers (Megonigal et al., 2004; Ye et al., 2014). As a result, consumption of the limited organic carbon supply by $\mathrm{SO}_{4}$ reducers should (and often does) limit methanogenic activity, such that terminal microbial respiration is typically dominated by $\mathrm{SO}_{4}$ reduction in brackish marshes (Sutton-Grier et al., 2011). Similarly, $\mathrm{SO}_{4}$ reducers are more efficient than methanogens at competing for the $\mathrm{H}_{2}$ required for $\mathrm{CO}_{2}$ reduction (Kristjansson et al., 1982). We did not measure rates of $\mathrm{SO}_{4}$ reduction in this study but can use $\mathrm{SO}_{4}$ depletion as a proxy; more $\mathrm{SO}_{4}$ depletion indicates that more $\mathrm{SO}_{4}$ reduction has occurred. Warming generally increased $\mathrm{SO}_{4}$ depletion, especially in the plots dominated by Schoenoplectus (Fig. 6b). Differences in $\mathrm{SO}_{4}$ depletion between plots are not driven by $\mathrm{SO}_{4}$ inputs because the only supply of $\mathrm{SO}_{4}$ is the tidal flow, which is the same for all plots in each community of the experiment. Instead, higher rates of $\mathrm{SO}_{4}$ reduction are most likely driven by some combination of electron donor supply and kinetics. While $\mathrm{SO}_{4}$ reducers likely benefited from the increased availability of electron donors, as described above, the kinetics of $\mathrm{SO}_{4}$ reduction also respond strongly to temperature (Weston and Joye, 2005).

When $\mathrm{SO}_{4}$ concentrations drop below a threshold concentration, $\mathrm{SO}_{4}$ reduction becomes $\mathrm{SO}_{4}$-limited, rather than electron-donor-limited (Megonigal et al., 2004). A review of the coastal wetland $\mathrm{CH}_{4}$ literature estimated this threshold at $4 \mathrm{mmol} \mathrm{SO}_{4}$ (Poffenbarger et al., 2011), a value that is consistent with patterns of porewater $\mathrm{CH}_{4}$ and $\mathrm{SO}_{4}$ at the GCReW site (Keller et al. 2009). As $\mathrm{SO}_{4}$ and $\mathrm{O}_{2}$ are the dominant electron-accepting compounds that suppress methanogenesis in this organic soil, this drawdown then re- leases the methanogens from substrate competition (Fig. 7, mechanism 3). Here, we show that $\mathrm{SO}_{4}$ is typically below $4 \mathrm{mmol}$ in the +5.1 plots in the $\mathrm{C}_{3}$ community and in all plots in the $\mathrm{C}_{4}$ community (Figs. 6, S5). The drawdown of $\mathrm{SO}_{4}$ may also reduce rates of anaerobic $\mathrm{CH}_{4}$ oxidation (Hinrichs and Boetius, 2003). Van Hulzen et al. (1999) proposed a multi-phase system in a warming incubation experiment, observing that first methanogens are outcompeted for substrates by other microbes, next $\mathrm{CH}_{4}$ production increases as the supply of inhibiting TEA decreases, and finally TEA availability is reduced to the point that methanogenesis is controlled only by the supply of electron donors. Warming in this study decreased the time required for the system to pass through the first two phases (van Hulzen et al., 1999). In our experiment, this final phase of increased methanogenic activity occurs when $\mathrm{SO}_{4}$ concentrations dip below $4 \mathrm{mmol} \mathrm{SO}_{4} \mathrm{~L}^{-1}$, which occurs most often in the $+5.1^{\circ} \mathrm{C}$ plots, especially in the $\mathrm{C}_{3}$ community. This interpretation is also supported by the longterm record of porewater chemistry from an allied experiment at the site, demonstrating that porewater $\mathrm{CH}_{4}$ concentrations increase as $\mathrm{SO}_{4}$ concentrations decrease (Keller et al., 2009).

Methanogens may also have a competitive advantage over $\mathrm{SO}_{4}$ reducers for electron donor consumption at warmer temperatures (van Hulzen et al., 1999). Sulfate reducers and methanogens have very similar $K_{\mathrm{M}}$ values for acetate, but the $K_{\mathrm{M}}$ for acetoclastic methanogenesis may decrease with temperature whereas $K_{\mathrm{M}}$ values for $\mathrm{SO}_{4}$ reducers increase with temperature (van Bodegom and Stams, 1999). If this is the case in our system, then warming would allow methanogens to use a greater proportion of the available substrates.

\subsection{Plant traits modify warming effects on $\mathrm{CH}_{4}$ cycling}

The three biogeochemical mechanisms we propose to explain a warming-induced increase in $\mathrm{CH}_{4}$ emissions should interact strongly with plant responses to warming. Relationships between plant functional groups and $\mathrm{CH}_{4}$ emissions have been demonstrated through field studies in other wetland ecosystems such as peatlands (Bubier et al., 1995; Ward et al., 2013) and in tidal wetland mesocosms (Liu et al., 2019; Martin and Moseman-Valtierra, 2017; Mueller et al., 2020). We provide field evidence that two species with distinct plant traits - Schoenoplectus and Spartina - have strikingly different effects on $\mathrm{CH}_{4}$ emissions from brackish wetlands. Spartina-dominated communities had consistently higher $\mathrm{CH}_{4}$ emissions under both ambient and warmed conditions (Fig. 3). In most years, Schoenoplectus biomass was negatively correlated with $\mathrm{CH}_{4}$ emissions, while Spartina and Distichlis biomass was positively correlated. Vegetation effects are typically strongest during the growing season, when the plants are actively altering rhizosphere biogeochemistry (van der Nat and Middelburg, 1998b; Ward et al., 2013), which is consistent with our observations in this study. 
As with warming effects, plant-driven shifts in $\mathrm{CH}_{4}$ emissions are the result of differing rates of $\mathrm{CH}_{4}$ production, oxidation, transport, or a combination of these processes, but sustained differences in emissions cannot be attributed only to transport, as discussed previously. Instead, the stimulation of $\mathrm{CH}_{4}$ emissions is likely due to changes in the plantmediated supply of electron acceptors and electron donors. In a field environment, differentiating between species-specific effects and underlying environmental conditions can be difficult, but mesocosm studies that control all environmental factors have also found species-specific effects on $\mathrm{CH}_{4}$ cycling (e.g., Liu et al., 2014). Plants can alter $\mathrm{CH}_{4}$ cycling by adding $\mathrm{O}_{2}$ (electron acceptor) or $\mathrm{C}$ substrates (electron donors) to the rhizosphere, altering the redox state. We propose that Schoenoplectus is a net oxidizer of the rhizosphere and that Spartina is a net reducer, and thus their presence and productivity have opposing effects on $\mathrm{CH}_{4}$ emissions (Fig. 7, mechanism 4).

\subsubsection{Schoenoplectus oxidizes the rhizosphere, increasing $\mathrm{CH}_{4}$ oxidation}

Species vary in their capacity to support aerobic $\mathrm{CH}_{4}$ oxidation (van der Nat and Middelburg, 1998b), and Schoenoplectus appears to support higher rates of aerobic $\mathrm{CH}_{4}$ oxidation than Spartina (Mueller et al., 2020). Scirpus lacustris is morphologically similar to Schoenoplectus americanus studied here and has been demonstrated to have substantial rhizosphere oxidation capacity, especially during the growing season (van der Nat and Middelburg, 1998b). Consequently, these plants likely exert stronger control on rates of $\mathrm{CH}_{4}$ oxidation than rates of methanogenesis (van der Nat and Middelburg, 1998a). We hypothesize that the relatively high capacity of Schoenoplectus to transport $\mathrm{O}_{2}$ held the $\mathrm{CH}_{4}$ emissions stimulation caused by modest levels of warming $\left(+1.7\right.$ to $\left.+3.4^{\circ} \mathrm{C}\right)$ to rates similar to under ambient conditions (Fig. 3). At high warming $\left(+5.1^{\circ} \mathrm{C}\right)$, however, Schoenoplectus community $\mathrm{CH}_{4}$ emissions drastically increase (Fig. 3). We suggest that this is due to the combined effects of the three mechanisms discussed previously, namely the differences in the $Q_{10}$ values of $\mathrm{CH}_{4}$ production and $\mathrm{CH}_{4}$ oxidation, the increased supply of organic substrate through plant productivity, and the decrease in competition for electron donors due to $\mathrm{SO}_{4}$ depletion. Collectively, when the ecosystem is warmed above current ambient conditions by $5^{\circ} \mathrm{C}$ or more, enhanced stimulation of $\mathrm{CH}_{4}$ production starts to offset some of the Schoenoplectus oxidation effect. This also offers an explanation for the positive correlation between Schoenoplectus biomass and $\mathrm{CH}_{4}$ emissions observed in 2016 as that was the hottest of the 4 years in this study.

\subsubsection{Spartina reduces the rhizosphere, increasing $\mathrm{CH}_{4}$ production}

The variability in quality and quantity of root exudates between plant functional types is well known to affect microbial community composition and activity (Deyn et al., 2008). Methanogenesis responses to warming in incubation studies are related to the lignin and cellulose content of the peat, which in turn depends on the plant functional type from which the peat developed (Duval and Radu, 2018). Although warming likely increases substrate availability across the whole experiment, the production of labile, low-molecular-weight $\mathrm{C}$ substrates through fermentation is less sensitive to temperature above $25^{\circ} \mathrm{C}$ than below this threshold (Neubauer and Craft, 2009; Weston and Joye, 2005). Microorganisms may also preferentially use freshly produced (i.e., labile) organic carbon compounds as electron donors (DeLaune et al., 2014), and consequently warming effects on $\mathrm{CH}_{4}$ production should be strongest in a system where rates of root exudation and turnover are most rapid. We propose that root exudation and turnover explain the positive correlation between plant biomass and $\mathrm{CH}_{4}$ emissions that we observed in the $\mathrm{C}_{4}$ community. Multiple years of porewater chemistry at this site show that Spartina-dominated communities have higher DOC and dissolved $\mathrm{CH}_{4}$ than adjacent Schoenoplectus communities (Keller et al., 2009; Marsh et al., 2005). Though we did not directly measure root exudation, porewater DOC is partially derived from root exudates and has been used as a proxy to understand the responses of root exudates to global change factors (Dieleman et al., 2016; Fenner et al., 2007; Jones et al., 2009).

We observed a simultaneous increase in dissolved $\mathrm{CH}_{4}$ at the soil surface and a decrease in dissolved $\mathrm{CH}_{4}$ at depth in the warmed $\mathrm{C}_{4}$ plots. As with the observed trends in $\mathrm{CH}_{4}$ emissions, there are multiple mechanisms that could cause a shift in porewater $\mathrm{CH}_{4}$ concentrations. Of the four mechanisms outlined above, perhaps the simplest explanation is an increase in labile $\mathrm{C}$ at shallow depths and a decrease in deeper soil. This is consistent with DOC depth profiles from this $\mathrm{C}_{4}$ community in which porewater DOC increases with warming in shallow samples but decreases with warming in deep samples (Fig. S7). This shallowing of peak DOC concentrations could be due to a warming-induced increase in evapotranspiration, leading to slower downward hydrologic transport of DOC-rich surface porewater to lower depths, or a warming-induced shallowing of the root system, leading to a shift in the location of root exudates.

In most years, Spartina biomass was positively correlated with $\mathrm{CH}_{4}$ emissions, supporting our hypothesis that Spartina favors net $\mathrm{CH}_{4}$ production. However, in 2016 Spartina biomass and $\mathrm{CH}_{4}$ emissions were negatively correlated. Prior work at this site has indicated that Spartina and Distichlis biomass is more negatively affected by hot and dry growing conditions than Schoenoplectus (Noyce et al., 2019) due in part because the Spartina and Distichlis $\left(\mathrm{C}_{4}\right)$ communities 
are less frequently inundated. The 2016 growing season was substantially warmer than average (Table 2), and the heating treatments were initialized on 1 June of that year, after the annual plants had already established and may have developed adaptations to ambient, rather than elevated, temperature conditions. The combination of these two effects likely led to heat stress, reducing the root exudates supplied to the rhizosphere microbial community (Heckathorn et al., 2013) and thus minimizing the Spartina stimulation effect.

\subsection{Comparisons with prior data}

Methane emissions have been measured at the GCReW site previously, but this study represents the most comprehensive dataset collected to date and is thus particularly useful for advancing the process-based understanding needed to improve prognostic models. Overall, our flux estimates are lower than those reported previously. The earliest $\mathrm{CH}_{4}$ fluxes were measured in a single month (July) in Schoenoplectus-dominated plots and reported to be 331 to $6883 \mu \mathrm{mol} \mathrm{m}^{-2} \mathrm{~d}^{-1}$ (Dacey et al., 1994), much higher than our range of 359 to $1651 \mu \mathrm{mol} \mathrm{m} \mathrm{m}^{-2} \mathrm{~d}^{-1}$ for ambient temperature Schoenoplectus plots in July. Similarly, Marsh et al. (2005) reported mean growing season (May-October) $\mathrm{CH}_{4}$ emissions from this site of $846 \pm 111 \mu \mathrm{mol} \mathrm{CH}_{4} \mathrm{~m}^{-2} \mathrm{~d}^{-1}$, whereas we measured $656 \pm 79 \mu \mathrm{mol} \mathrm{CH} \mathrm{CH}_{4} \mathrm{~m}^{-2} \mathrm{~d}^{-1}$ over the same months. Finally, Pastore et al. (2017) estimated average annual fluxes in their Schoenoplectus-dominated ambient $\mathrm{CO}_{2}$ plots as $3.1 \pm 1.7 \mathrm{~g} \mathrm{CH}_{4} \mathrm{~m}^{-2} \mathrm{yr}^{-1}$, compared to our estimates of $1.6 \pm 0.3 \mathrm{~g} \mathrm{CH}_{4} \mathrm{~m}^{-2} \mathrm{yr}^{-1}$ for Schoenoplectus plots. The different estimates by these studies may be partly due to interannual variability as demonstrated in our data where 2018 had substantially higher fluxes than any of the surrounding years (Table S2).

The annual estimates reported here for ambient temperature plots trended lower than published mean $\mathrm{CH}_{4}$ emissions for mesohaline tidal marshes. Our plots ranged from 0.7 to $9.3 \mathrm{~g} \mathrm{CH}_{4} \mathrm{~m}^{-2} \mathrm{yr}^{-1}$ (mean $=9.3$ ), compared to the range of 3.3 to $16.4 \mathrm{~g} \mathrm{CH}_{4} \mathrm{~m}^{-2} \mathrm{yr}^{-1}$ (mean $=16.4$ ) reported by Poffenbarger et al. (2011). This difference may be explained by the fact that there was significant within-class variation in the oligohaline and mesohaline salinity classes that was unexplained, and their assessment was based on too few data points to fully capture the variation that is expected to exist in the mesohaline class. Indeed, subsequent studies have documented fluxes well below $3 \mathrm{~g} \mathrm{CH}_{4} \mathrm{~m}^{-2} \mathrm{yr}^{-1}$ (Krauss and Whitbeck, 2012) and even negative fluxes (Al-Haj and Fulweiler, 2020). We hypothesize that the low fluxes measured at our site reflect Schoenoplectus americanus traits that favor $\mathrm{CH}_{4}$ oxidation more than $\mathrm{CH}_{4}$ production and that the high end of our range was limited by the high soil elevation (i.e., deep water table) of areas dominated by Spartina patens, offsetting the influence of $S$. patens traits that favor $\mathrm{CH}_{4}$ production.

\subsection{Implications for tidal wetland carbon cycling}

Warming accelerates rates of $\mathrm{CH}_{4}$ emissions from brackish marshes, especially during the growing season. This is driven by both direct and indirect warming effects and mediated by soil biogeochemistry, but the magnitude of the warming effect is also dependent on traits of the plant species that dominate the plant community. Communities dominated by Spartina patens increase net $\mathrm{CH}_{4}$ emissions in response to smaller increments of warming than communities dominated by Schoenoplectus americanus. Spartina-dominated sites may thus have a higher likelihood of shifting from a net $\mathrm{C}$ sink to a net $\mathrm{C}$ source under future warming conditions, due to this increased loss of $\mathrm{C}$ as $\mathrm{CH}_{4}$. However, this effect could be mitigated if these high-elevation Spartina marshes become dominated by Schoenoplectus in response to predicted accelerated sea-level rise (Kirwan and Guntenspergen, 2012). In addition, Spartina traits are plastic and influenced by factors such as soil redox conditions (Kludze and DeLaune, 1994), salinity (Crozier and DeLaune, 1996), and water level (Liu et al., 2019), all of which can be expected to change plant-mediated effects on $\mathrm{CH}_{4}$ biogeochemistry. Further studies are needed to thoroughly assess the range of environmental conditions under which Spartina is a net reducer and Schoenoplectus is a net oxidizer as proposed by the present study.

Data availability. All data are available from the corresponding author upon request.

Supplement. The supplement related to this article is available online at: https://doi.org/10.5194/bg-18-2449-2021-supplement.

Author contributions. GLN and JPM designed the study, GLN collected and analyzed the data, and GLN and JPM wrote the paper.

Competing interests. The authors declare that they have no conflict of interest.

Acknowledgements. Roy Rich designed the warming infrastructure and maintains it with the assistance of Gary Peresta. We also thank the technicians in the SERC Biogeochemistry Lab for assistance with porewater collection and analysis. 
Financial support. This research has been supported by the US Department of Energy, Office of Science, Office of Biological and Environmental Research program (grant nos. DE-SC0014413 and DE-SC0019110); the National Science Foundation Long-Term Research in Environmental Biology program (grant nos. DEB0950080, DEB-1457100, and DEB-1557009); and the Smithsonian Institution.

Review statement. This paper was edited by Edzo Veldkamp and reviewed by two anonymous referees.

\section{References}

Al-Haj, A. N. and Fulweiler, R. W.: A synthesis of methane emissions from shallow vegetated coastal ecosystems, Global Change Biol., 26, 2988-3005, https://doi.org/10.1111/gcb.15046, 2020.

Bardgett, R. D., Bowman, W. D., Kaufmann, R., and Schmidt, S. K.: A temporal approach to linking aboveground and belowground ecology, Trends Ecol. Evol., 20, 634-641, https://doi.org/10.1016/j.tree.2005.08.005, 2005.

Basiliko, N., Stewart, H., Roulet, N. T., and Moore, T. R.: Do root exudates enhance peat decomposition?, Geomicrobiol. J., 29, 374-378, https://doi.org/10.1080/01490451.2011.568272, 2012.

Bianchi, T. S.: Biogeochemistry of Estuaries, Oxford University Press, New York, USA, 720 pp., 2006.

Blaser, M. and Conrad, R.: Stable carbon isotope fractionation as tracer of carbon cycling in anoxic soil ecosystems, Curr. Opin. Biotech., 41, 122-129, https://doi.org/10.1016/j.copbio.2016.07.001, 2016.

Bridgham, S. D., Megonigal, J. P., Keller, J. K., Bliss, N. B., and Trettin, C.: The carbon balance of North American wetlands, Wetlands, 26, 889-916, https://doi.org/10.1672/02775212(2006)26[889:TCBONA]2.0.CO;2, 2006.

Bridgham, S. D., Cadillo-Quiroz, H., Keller, J. K., and Zhuang, Q.: Methane emissions from wetlands: biogeochemical, microbial, and modeling perspectives from local to global scales, Global Change Biol., 19, 1325-1346, https://doi.org/10.1111/gcb.12131, 2013.

Bubier, J. L., Moore, T. R., Bellisario, L., Comer, N. T., and Crill, P. M.: Ecological controls on methane emissions from a Northern Peatland Complex in the zone of discontinuous permafrost, Manitoba, Canada, Global Biogeochem. Cy., 9, 455470, https://doi.org/10.1029/95GB02379, 1995.

Chen, J., Luo, Y., Xia, J., Wilcox, K. R., Cao, J., Zhou, X., Jiang, L., Niu, S., Estera, K. Y., Huang, R., Wu, F., Hu, T., Liang, J., Shi, Z., Guo, J., and Wang, R.-W.: Warming effects on ecosystem carbon fluxes are modulated by plant functional types, Ecosystems, 20, 515-526, https://doi.org/10.1007/s10021-016-0035-6, 2017.

Christensen, T. R., Ekberg, A., Ström, L., Mastepanov, M., Panikov, N., Öquist, M., Svensson, B. H., Nykänen, H., Martikainen, P. J., and Oskarsson, H.: Factors controlling large scale variations in methane emissions from wetlands, Geophys. Res. Lett., 30, 1414, https://doi.org/10.1029/2002GL016848, 2003.

Conrad, R.: Quantification of methanogenic pathways using stable carbon isotopic signatures: a review and a proposal, Org. Geochem., 36, 739-752, https://doi.org/10.1016/j.orggeochem.2004.09.006, 2005.
Conrad, R.: Importance of hydrogenotrophic, aceticlastic and methylotrophic methanogenesis for methane production in terrestrial, aquatic and other anoxic environments: A mini review, Pedosphere, 30, 25-39, https://doi.org/10.1016/S10020160(18)60052-9, 2020.

Crozier, C. R. and DeLaune, R. D.: Methane production by soils from different Louisiana marsh vegetation types, Wetlands, 16, 121-126, https://doi.org/10.1007/BF03160685, 1996.

Dacey, J. W. H., Drake, B. G., and Klug, M. J.: Stimulation of methane emission by carbon dioxide enrichment of marsh vegetation, Nature, 370, 47-49, https://doi.org/10.1038/370047a0, 1994.

de Jong, A. E. E., in't Zandt, M. H., Meisel, O. H., Jetten, M. S. M., Dean, J. F., Rasigraf, O., and Welte, C. U.: Increases in temperature and nutrient availability positively affect methane-cycling microorganisms in Arctic thermokarst lake sediments, Environ. Microbiol., 20, 4314-4327, https://doi.org/10.1111/14622920.14345, 2018.

Delarue, F., Gogo, S., Buttler, A., Bragazza, L., Jassey, V. E. J., Bernard, G., and Laggoun-Défarge, F.: Indirect effects of experimental warming on dissolved organic carbon content in subsurface peat, J. Soils Sediments, 14, 1800-1805, https://doi.org/10.1007/s11368-014-0945-x, 2014.

Deyn, G. B. D., Cornelissen, J. H. C., and Bardgett, R. D.: Plant functional traits and soil carbon sequestration in contrasting biomes, Ecol. Lett., 11, 516-531, https://doi.org/10.1111/j.14610248.2008.01164.x, 2008.

Dieleman, C. M., Lindo, Z., McLaughlin, J. W., Craig, A. E., and Branfireun, B. A.: Climate change effects on peatland decomposition and porewater dissolved organic carbon biogeochemistry, Biogeochemistry, 128, 385-396, https://doi.org/10.1007/s10533016-0214-8, 2016.

Ding, W., Cai, Z., and Tsuruta, H.: Plant species effects on methane emissions from freshwater marshes, Atmos. Environ., 39, 31993207, https://doi.org/10.1016/j.atmosenv.2005.02.022, 2005.

Dise, N. B., Gorham, E., and Verry, E. S.: Environmental factors controlling methane emissions from peatlands in northern Minnesota, J. Geophys. Res.-Atmos., 98, 10583-10594, https://doi.org/10.1029/93JD00160, 1993.

Duval, T. P. and Radu, D. D.: Effect of temperature and soil organic matter quality on greenhouse-gas production from temperate poor and rich fen soils, Ecol. Eng., 114, 66-75, https://doi.org/10.1016/j.ecoleng.2017.05.011, 2018.

Environmental Protection Agency: Inventory of US Greenhouse Gas Emissions and Sinks: 1990-2015, Environmental Protection Agency, 633 pp., Washington, DC, USA, 2017.

Fenner, N., Freeman, C., Lock, M. A., Harmens, H., Reynolds, B., and Sparks, T.: Interactions between elevated $\mathrm{CO}_{2}$ and warming could amplify DOC exports from peatland catchments, Environ. Sci. Technol., 41, 3146-3152, https://doi.org/10.1021/es061765v, 2007.

Fey, A. and Conrad, R.: Effect of temperature on carbon and electron flow and on the archaeal community in methanogenic rice field soil, Appl. Environ. Microb., 66, 4790-4797, https://doi.org/10.1128/AEM.66.11.4790-4797.2000, 2000.

He, S., Malfatti, S. A., McFarland, J. W., Anderson, F. E., Pati, A., Huntemann, M., Tremblay, J., del Rio, T. G., Waldrop, M. P., Windham-Myers, L., and Tringe, S. G.: Patterns in wetland microbial community composition and functional gene reper- 
toire associated with methane emissions, mBio, 6, e00066-15, https://doi.org/10.1128/mBio.00066-15, 2015.

Heckathorn, S. A., Giri, A., Mishra, S., and Bista, D.: Heat Stress and Roots, in: Climate Change and Plant Abiotic Stress Tolerance, John Wiley \& Sons Ltd., Weinheim, Germany, 109-136, https://doi.org/10.1002/9783527675265.ch05, 2013.

Hinrichs, K.-U. and Boetius, A.: The Anaerobic Oxidation of Methane: New Insights in Microbial Ecology and Biogeochemistry, in: Ocean Margin Systems, edited by: Wefer, G., Billett, D., Hebbeln, D., Jørgensen, B. B., Schlüter, M., and van Weering, T. C. E., Springer, Berlin, Heidelberg, Germany, 457-477, https://doi.org/10.1007/978-3-662-05127-6_28, 2003.

Holmquist, J. R., Windham-Myers, L., Bliss, N., Crooks, S., Morris, J. T., Megonigal, J. P., Troxler, T., Weller, D., Callaway, J., Drexler, J., Ferner, M. C., Gonneea, M. E., Kroeger, K. D., Schile-Beers, L., Woo, I., Buffington, K., Breithaupt, J., Boyd, B. M., Brown, L. N., Dix, N., Hice, L., Horton, B. P., MacDonald, G. M., Moyer, R. P., Reay, W., Shaw, T., Smith, E., Smoak, J. M., Sommerfield, C., Thorne, K., Velinsky, D., Watson, E., Grimes, K. W., and Woodrey, M.: Accuracy and precision of tidal wetland soil carbon mapping in the conterminous United States, Sci. Rep.-UK, 8, 9478, https://doi.org/10.1038/s41598-018-26948-7, 2018.

Hopple, A. M., Wilson, R. M., Kolton, M., Zalman, C. A., Chanton, J. P., Kostka, J., Hanson, P. J., Keller, J. K., and Bridgham, S. D.: Massive peatland carbon banks vulnerable to rising temperatures, Nat. Commun., 11, 2373, https://doi.org/10.1038/s41467020-16311-8, 2020.

Hosono, T. and Nouchi, I.: The dependence of methane transport in rice plants on the root zone temperature, Plant Soil, 191, 233240, https://doi.org/10.1023/A:1004203208686, 1997.

Inglett, K. S., Inglett, P. W., Reddy, K. R., and Osborne, T. Z.: Temperature sensitivity of greenhouse gas production in wetland soils of different vegetation, Biogeochemistry, 108, 77-90, https://doi.org/10.1007/s10533-011-9573-3, 2012.

IPCC: Climate Change 2013: The Physical Science Basis, Working Group I Contribution to the Fifth Assessment Report of the Intergovernmental Panel on Climate Change, Cambridge University Press, Cambridge, UK, 2013.

Jones, T. G., Freeman, C., Lloyd, A., and Mills, G.: Impacts of elevated atmospheric ozone on peatland belowground DOC characteristics, Ecol. Eng., 35, 971-977, https://doi.org/10.1016/j.ecoleng.2008.08.009, 2009.

Kayranli, B., Scholz, M., Mustafa, A., and Hedmark, Å.: Carbon storage and fluxes within freshwater wetlands: A critical review, Wetlands, 30, 111-124, https://doi.org/10.1007/s13157009-0003-4, 2010.

Keller, J. K., Wolf, A. A., Weisenhorn, P. B., Drake, B. G., and Megonigal, J. P.: Elevated $\mathrm{CO}_{2}$ affects porewater chemistry in a brackish marsh, Biogeochemistry, 96, 101-117, https://doi.org/10.1007/s10533-009-9347-3, 2009.

Kirwan, M. L. and Guntenspergen, G. R.: Feedbacks between inundation, root production, and shoot growth in a rapidly submerging brackish marsh, J. Ecol., 100, 764-770, https://doi.org/10.1111/j.1365-2745.2012.01957.x, 2012.

Kludze, H. K. and DeLaune, R. D.: Methane emissions and growth of Spartina patens in response to soil redox intensity, Soil Sci. Soc. Am. J., 58, 1838-1845, https://doi.org/10.2136/sssaj1994.03615995005800060037x, 1994.

Krauss, K. W. and Whitbeck, J. L.: Soil greenhouse gas fluxes during wetland forest retreat along the Lower Savannah River, Georgia (USA), Wetlands, 32, 73-81, https://doi.org/10.1007/s13157011-0246-8, 2012.

Kristjansson, J. K., Schönheit, P., and Thauer, R. K.: Different Ks values for hydrogen of methanogenic bacteria and sulfate reducing bacteria: An explanation for the apparent inhibition of methanogenesis by sulfate, Arch. Microbiol., 131, 278-282, https://doi.org/10.1007/BF00405893, 1982.

Lenzewski, N., Mueller, P., Meier, R. J., Liebsch, G., Jensen, K., and Koop-Jakobsen, K.: Dynamics of oxygen and carbon dioxide in rhizospheres of Lobelia dortmanna - a planar optode study of belowground gas exchange between plants and sediment, New Phytol., 218, 131-141, https://doi.org/10.1111/nph.14973, 2018.

Liu, D., Ding, W., Yuan, J., Xiang, J., and Lin, Y.: Substrate and/or substrate-driven changes in the abundance of methanogenic archaea cause seasonal variation of methane production potential in species-specific freshwater wetlands, Appl. Microbiol. Biot., 98, 4711-4721, https://doi.org/10.1007/s00253-014-55714, 2014

Liu, L., Wang, D., Chen, S., Yu, Z., Xu, Y., Li, Y., Ge, Z., and Chen, Z.: Methane emissions from estuarine coastal wetlands: Implications for global change effect, Soil Sci. Soc. Am. J., 83, 13681377, https://doi.org/10.2136/sssaj2018.12.0472, 2019.

Lu, M., Caplan, J. S., Bakker, J. D., Langley, J. A., Mozdzer, T. J., Drake, B. G., and Megonigal, J. P.: Allometry data and equations for coastal marsh plants, Ecology, 97, p. 3554, https://doi.org/10.1002/ecy.1600, 2016.

Marsh, A. S., Rasse, D. P., Drake, B. G., and Patrick Megonigal, J.: Effect of elevated $\mathrm{CO}_{2}$ on carbon pools and fluxes in a brackish marsh, Estuaries, 28, 694-704, https://doi.org/10.1007/BF02732908, 2005.

Martin, R. M. and Moseman-Valtierra, S.: Different short-term responses of greenhouse gas fluxes from salt marsh mesocosms to simulated global change drivers, Hydrobiologia, 802, 71-83, https://doi.org/10.1007/s10750-017-3240-1, 2017.

Mcleod, E., Chmura, G. L., Bouillon, S., Salm, R., Björk, M., Duarte, C. M., Lovelock, C. E., Schlesinger, W. H., and Silliman, B. R.: A blueprint for blue carbon: toward an improved understanding of the role of vegetated coastal habitats in sequestering $\mathrm{CO}_{2}$, Front. Ecol. Environ., 9, 552-560, https://doi.org/10.1890/110004, 2011.

Megonigal, J. P. and Schlesinger, W. H.: Methane-limited methanotrophy in tidal freshwater swamps, Global Biogeochem. Cy., 16, 1088, https://doi.org/10.1029/2001GB001594, 2002.

Megonigal, J. P., Whalen, S. C., Tissue, D. T., Bovard, B. D., Allen, A. S., and Albert, D. B.: A plant-soil-atmosphere microcosm for tracing radiocarbon from photosynthesis through methanogenesis, Soil Sci. Soc. Am. J., 63, 665-671, https://doi.org/10.2136/sssaj1999.03615995006300030033x, 1999.

Megonigal, J. P., Hines, M. E., and Visscher, P. T.: Anaerobic metabolism: linkages to trace gases and aerobic processes, in: Biogeochemistry, edited by: Schlesinger, W. H., ElsevierPergamon, Oxford, UK, 317-424, 2004.

Megonigal, J. P., Chapman, S., Crooks, S., Dijkstra, P., Kirwan, M., and Langley, A.: 3.4 Impacts and effects of ocean warming on 
tidal marsh and tidal freshwater forest ecosystems, in: Explaining Ocean Warming: Causes, scale, effects, and consequences, IUCN, Gland, Switzerland, 2016.

Moor, H., Rydin, H., Hylander, K., Nilsson, M. B., Lindborg, R., and Norberg, J.: Towards a trait-based ecology of wetland vegetation, J. Ecol., 105, 1623-1635, https://doi.org/10.1111/13652745.12734, 2017.

Mueller, P., Jensen, K., and Megonigal, J. P.: Plants mediate soil organic matter decomposition in response to sea level rise, Global Change Biol., 22, 404-414, https://doi.org/10.1111/gcb.13082, 2016.

Mueller, P., Mozdzer, T. J., Langley, J. A., Aoki, L. R., Noyce, G. L., and Megonigal, J. P.: Plants determine methane response to sea level rise, Nat. Commun., https://doi.org/10.1038/s41467020-18763-4, 2020.

Neubauer, S. C. and Craft, C. B.: Global Change and Tidal Freshwater Wetlands: Scenarios and Impacts, in: Tidal Freshwater Wetlands, edited by: Barendregt, A., Whigham, D., and Baldwin, A., Margraf Publishers, Weikersheim, Germany, 253-310, 2009.

Neubauer, S. C. and Megonigal, J. P.: Moving beyond global warming potentials to quantify the climatic role of ecosystems, Ecosystems, 18, 1000-1013, https://doi.org/10.1007/s10021015-9879-4, 2015.

Neubauer, S. C., Emerson, D., and Megonigal, J. P.: Microbial oxidation and reduction of Iron in the root zone and influences on metal mobility, in: Biophysico-Chemical Processes of Heavy Metals and Metalloids in Soil Environments, John Wiley \& Sons Ltd., Hoboken, New Jersey, 339-371, https://doi.org/10.1002/9780470175484.ch9, 2008.

Neumann, R. B., Blazewicz, S. J., Conaway, C. H., Turetsky, M. R., and Waldrop, M. P.: Modeling $\mathrm{CH}_{4}$ and $\mathrm{CO}_{2}$ cycling using porewater stable isotopes in a thermokarst bog in Interior Alaska: results from three conceptual reaction networks, Biogeochemistry, 127, 57-87, https://doi.org/10.1007/s10533-015-0168-2, 2016.

Noyce, G. L., Kirwan, M. L., Rich, R. L., and Megonigal, J. P.: Asynchronous nitrogen supply and demand produce non-linear plant allocation responses to warming and elevated $\mathrm{CO}_{2}$, P. Natl. Acad. Sci. USA, 116, 21623-21628, https://doi.org/10.1073/pnas.1904990116, 2019.

Oremland, R. S., Marsh, L. M., and Polcin, S.: Methane production and simultaneous sulphate reduction in anoxic, salt marsh sediments, Nature, 296, 143-145, https://doi.org/10.1038/296143a0, 1982.

Pastore, M. A., Megonigal, J. P., and Langley, J. A.: Elevated $\mathrm{CO}_{2}$ and nitrogen addition accelerate net carbon gain in a brackish marsh, Biogeochemistry, 133, 73-87, https://doi.org/10.1007/s10533-017-0312-2, 2017.

Pendleton, L., Donato, D. C., Murray, B. C., Crooks, S., Jenkins, W. A., Sifleet, S., Craft, C., Fourqurean, J. W., Kauffman, J. B., Marbà, N., Megonigal, P., Pidgeon, E., Herr, D., Gordon, D., and Baldera, A.: Estimating global "blue carbon" emissions from conversion and degradation of vegetated coastal ecosystems, PloS One, 7, e43542, https://doi.org/10.1371/journal.pone.0043542, 2012.

Philippot, L., Hallin, S., Börjesson, G., and Baggs, E. M.: Biochemical cycling in the rhizosphere having an impact on global change, Plant Soil, 321, 61-81, https://doi.org/10.1007/s11104008-9796-9, 2009.
Poffenbarger, H. J., Needelman, B. A., and Megonigal, J. P.: Salinity influence on methane emissions from tidal marshes, Wetlands, 31, 831-842, https://doi.org/10.1007/s13157-011-0197-0, 2011.

Rich, R. L., Stefanski, A., Montgomery, R. A., Hobbie, S. E., Kimball, B. A., and Reich, P. B.: Design and performance of combined infrared canopy and belowground warming in the B4WarmED (Boreal Forest Warming at an Ecotone in Danger) experiment, Global Change Biol., 21, 2334-2348, https://doi.org/10.1111/gcb.12855, 2015.

Robroek, B. J. M., Albrecht, R. J. H., Hamard, S., Pulgarin, A., Bragazza, L., Buttler, A., and Jassey, V. E.: Peatland vascular plant functional types affect dissolved organic matter chemistry, Plant Soil, 407, 135-143, https://doi.org/10.1007/s11104-0152710-3, 2016.

Roden, E. E. and Wetzel, R. G.: Organic carbon oxidation and suppression of methane production by microbial $\mathrm{Fe}(\mathrm{III})$ oxide reduction in vegetated and unvegetated freshwater wetland sediments, Limnol. Oceanogr., 41, 1733-1748, https://doi.org/10.4319/lo.1996.41.8.1733, 1996.

Saunois, M., Bousquet, P., Poulter, B., Peregon, A., Ciais, P., Canadell, J. G., Dlugokencky, E. J., Etiope, G., Bastviken, D., Houweling, S., Janssens-Maenhout, G., Tubiello, F. N., Castaldi, S., Jackson, R. B., Alexe, M., Arora, V. K., Beerling, D. J., Bergamaschi, P., Blake, D. R., Brailsford, G., Brovkin, V., Bruhwiler, L., Crevoisier, C., Crill, P., Covey, K., Curry, C., Frankenberg, C., Gedney, N., Höglund-Isaksson, L., Ishizawa, M., Ito, A., Joos, F., Kim, H.-S., Kleinen, T., Krummel, P., Lamarque, J.-F., Langenfelds, R., Locatelli, R., Machida, T., Maksyutov, S., McDonald, K. C., Marshall, J., Melton, J. R., Morino, I., Naik, V., O’Doherty, S., Parmentier, F.-J. W., Patra, P. K., Peng, C., Peng, S., Peters, G. P., Pison, I., Prigent, C., Prinn, R., Ramonet, M., Riley, W. J., Saito, M., Santini, M., Schroeder, R., Simpson, I. J., Spahni, R., Steele, P., Takizawa, A., Thornton, B. F., Tian, H., Tohjima, Y., Viovy, N., Voulgarakis, A., van Weele, M., van der Werf, G. R., Weiss, R., Wiedinmyer, C., Wilton, D. J., Wiltshire, A., Worthy, D., Wunch, D., Xu, X., Yoshida, Y., Zhang, B., Zhang, Z., and Zhu, Q.: The global methane budget 2000-2012, Earth Syst. Sci. Data, 8, 697-751, https://doi.org/10.5194/essd-8-697-2016, 2016.

Schlesinger, W. H. and Bernhardt, E. S.: Biogeochemistry: An Analysis of Global Change, edn. 4, Academic Press, Waltham, Massachusetts, USA, 2020.

Segers, R.: Methane production and methane consumption: A review of processes underlying wetland methane fluxes, Biogeochemistry, 41, 23-51, https://doi.org/10.1023/A:1005929032764, 1998.

Sihi, D., Inglett, P. W., Gerber, S., and Inglett, K. S.: Rate of warming affects temperature sensitivity of anaerobic peat decomposition and greenhouse gas production, Global Change Biol., 24, 259-274, https://doi.org/10.1111/gcb.13839, 2017.

Sorrell, B. K., Brix, H., Schierup, H.-H., and Lorenzen, B.: Dieback of Phragmites australis: Influence on the distribution and rate of sediment methanogenesis, Biogeochemistry, 36, 173-188, https://doi.org/10.1023/A:1005761609386, 1997.

Stanley, E. H. and Ward, A. K.: Effects of vascular plants on seasonal pore water carbon dynamics in a lotic wetland, Wetlands, 30, 889-900, https://doi.org/10.1007/s13157-010-0087-x, 2010.

Sutton-Grier, A. E., Keller, J. K., Koch, R., Gilmour, C., and Megonigal, J. P.: Electron donors and acceptors 
influence anaerobic soil organic matter mineralization in tidal marshes, Soil Biol. Biochem., 43, 1576-1583, https://doi.org/10.1016/j.soilbio.2011.04.008, 2011.

van Bodegom, P. M. and Stams, A. J. M.: Effects of alternative electron acceptors and temperature on methanogenesis in rice paddy soils, Chemosphere, 39, 167-182, https://doi.org/10.1016/S0045-6535(99)00101-0, 1999.

van der Nat, F.-J. W. A. and Middelburg, J. J.: Effects of two common macrophytes on methane dynamics in freshwater sediments, Biogeochemistry, 43, 79-104, https://doi.org/10.1023/A:1006076527187, 1998a.

van der Nat, F.-J. W. A. and Middelburg, J. J.: Seasonal variation in methane oxidation by the rhizosphere of Phragmites australis and Scirpus lacustris, Aquat. Bot., 61, 95-110, https://doi.org/10.1016/S0304-3770(98)00072-2, 1998b.

van Hulzen, J. B., Segers, R., van Bodegom, P. M., and Leffelaar, P. A.: Temperature effects on soil methane production: an explanation for observed variability, Soil Biol. Biochem., 31, 19191929, https://doi.org/10.1016/S0038-0717(99)00109-1, 1999.

Vann, C. D. and Megonigal, J. P.: Elevated $\mathrm{CO}_{2}$ and water depth regulation of methane emissions: Comparison of woody and nonwoody wetland plant species, Biogeochemistry, 63, 117-134, https://doi.org/10.1023/A:1023397032331, 2003.

Waldo, N. B., Hunt, B. K., Fadely, E. C., Moran, J. J., and Neumann, R. B.: Plant root exudates increase methane emissions through direct and indirect pathways, Biogeochemistry, 145, 213-234, https://doi.org/10.1007/s10533-019-00600-6, 2019.

Ward, S. E., Ostle, N. J., Oakley, S., Quirk, H., Henrys, P. A., and Bardgett, R. D.: Warming effects on greenhouse gas fluxes in peatlands are modulated by vegetation composition, Ecol. Lett., 16, 1285-1293, https://doi.org/10.1111/ele.12167, 2013.

Wassmann, R., Alberto, M. C., Tirol-Padre, A., Hoang, N. T., Romasanta, R., Centeno, C. A., and Sander, B. O.: Increasing sensitivity of methane emission measurements in rice through deployment of "closed chambers" at nighttime, PloS One, 13, e0191352, https://doi.org/10.1371/journal.pone.0191352, 2018.

Weiss, J. V., Emerson, D., and Megonigal, J. P.: Geochemical control of microbial $\mathrm{Fe}(\mathrm{III})$ reduction potential in wetlands: comparison of the rhizosphere to non-rhizosphere soil, FEMS Microbiol. Ecol., 48, 89-100, https://doi.org/10.1016/j.femsec.2003.12.014, 2004.
Weston, N. B. and Joye, S. B.: Temperature-driven decoupling of key phases of organic matter degradation in marine sediments, P. Natl. Acad. Sci. USA, 102, 17036-17040, https://doi.org/10.1073/pnas.0508798102, 2005.

Whiticar, M. J.: Carbon and hydrogen isotope systematics of bacterial formation and oxidation of methane, Chem. Geol., 161, 291314, https://doi.org/10.1016/S0009-2541(99)00092-3, 1999.

Wilson, R. M., Hopple, A. M., Tfaily, M. M., Sebestyen, S. D., Schadt, C. W., Pfeifer-Meister, L., Medvedeff, C., McFarlane, K. J., Kostka, J. E., Kolton, M., Kolka, R. K., Kluber, L. A., Keller, J. K., Guilderson, T. P., Griffiths, N. A., Chanton, J. P., Bridgham, S. D., and Hanson, P. J.: Stability of peatland carbon to rising temperatures, Nat. Commun., 7, 13723, https://doi.org/10.1038/ncomms13723, 2016.

Yang, P., Wang, M. H., Lai, D. Y. F., Chun, K. P., Huang, J. F., Wan, S. A., Bastviken, D., and Tong, C.: Methane dynamics in an estuarine brackish Cyperus malaccensis marsh: Production and porewater concentration in soils, and net emissions to the atmosphere over five years, Geoderma, 337, 132-142, https://doi.org/10.1016/j.geoderma.2018.09.019, 2019.

Yang, Z., Wullschleger, S. D., Liang, L., Graham, D. E., and $\mathrm{Gu}$, B.: Effects of warming on the degradation and production of low-molecular-weight labile organic carbon in an Arctic tundra soil, Soil Biol. Biochem., 95, 202-211, https://doi.org/10.1016/j.soilbio.2015.12.022, 2016.

Ye, R., Jin, Q., Bohannan, B., Keller, J. K., and Bridgham, S. D.: Homoacetogenesis: A potentially underappreciated carbon pathway in peatlands, Soil Biol. Biochem., 68, 385-391, https://doi.org/10.1016/j.soilbio.2013.10.020, 2014.

Yvon-Durocher, G., Allen, A. P., Bastviken, D., Conrad, R., Gudasz, C., St-Pierre, A., Thanh-Duc, N., and del Giorgio, P. A.: Methane fluxes show consistent temperature dependence across microbial to ecosystem scales, Nature, 507, 488-491, https://doi.org/10.1038/nature13164, 2014. 